\title{
1. INTRODUCTION AND SUMMARY: HYDROTHERMAL CIRCULATION IN THE OCEANIC CRUST AND ITS CONSEQUENCES ON THE EASTERN FLANK OF THE JUAN DE FUCA RIDGE ${ }^{1}$
}

\author{
Shipboard Scientific Party ${ }^{2}$
}

\section{OVERVIEW}

Simple examples of several common hydrothermal flow regimes have been found on the eastern flank of the Juan de Fuca Ridge. Ocean Drilling Program (ODP) Leg 168 focused on three of these, at sites where it has been inferred that (1) there is a sharp transition from sediment-free to sediment-covered igneous crust, where heat flow, crustal temperatures, basement-fluid compositions, and upper crustal seismic velocities all show large systematic changes associated with the transition from open to closed hydrothermal circulation; (2) regionally continuous sediment cover restricts or prevents local advective heat loss from the igneous crust and fluid exchange between the ocean and the buried igneous basement; and (3) fluid flow within the igneous crust and through the seafloor is strongly influenced by local basement relief and sediment-thickness variations. Because of their unusual simplicity in the Leg 168 area, these examples provide ideal targets for drilling. Because they are representative of situations that are common in all ocean basins, lessons learned should have global implications. Sampling, downhole measurements, and post-drilling observations during Leg 168 were directed mainly toward elucidating the fundamental physics and fluid chemistry of ridge-flank hydrothermal circulation and the consequent alteration of the upper igneous crust and sediments that host the flow. Specifically, this was accomplished through a transect of relatively shallow holes that provided direct information about lateral gradients of basement-fluid composition, formation pressures, and temperatures, and strong constraints on formation-scale fluid- and heat-transport properties of the upper igneous crust and on the rates of circulation.

\section{BACKGROUND}

Although the most spectacular manifestation of oceanic crustal fluid circulation is found along mid-ocean ridge axes in the form of high-temperature $\left(350^{\circ}-400^{\circ} \mathrm{C}\right)$ springs that deposit metal sulfide minerals, a far greater flux of both heat and seawater occurs via hydrothermal circulation in the igneous crust of mid-ocean ridge flanks. Modeling and observations of heat flow indicate that advective heat loss through ridge flanks is globally more than triple that at ridge axes, and because this heat is lost at lower temperatures, the volumetric flux of seawater through the flanks is proportionately greater, more than 10 times that at the axes. Significant hydrothermal heat loss and fluid exchange between the crust and ocean typically continue to an age of several tens of millions of years and thus affect more than onethird of the ocean floor (Anderson et al., 1977; Sclater et al., 1976). This process plays an important role in the alteration of oceanic crust, which includes changes in its chemistry, mineralogy, and physical properties such as seismic velocity and attenuation (Alt et al., 1986;

${ }^{1}$ Davis, E.E., Fisher, A.T., Firth, J.V., et al., 1997. Proc. ODP, Init. Repts, 168 College Station, TX (Ocean Drilling Program).

${ }^{2}$ Shipboard Scientific Party is given in the list preceding the Table of Contents.
Purdy, 1987; Rohr, 1994). However, because of the wide range of conditions on ridge flanks, and the limited amount of work done there to date, we know little about these processes in detail. Major questions remain: how does thermal buoyancy operate to drive fluid flow through the crust and seafloor, what is the magnitude of elemental chemical exchange between the crust and water column, and what factors are most important in influencing water/rock interactions and, thus, in controlling fluid chemistry and the chemical and physical alteration of the igneous crust and its sediment cover?

Over the past two decades, several sites of hydrothermal circulation on mid-ocean ridge flanks have been investigated. These include the Galapagos mounds (Williams et al., 1974; Green et al., 1981; Becker and Von Herzen, 1983), the southern flank of the Costa Rica Rift (Langseth et al., 1988; Mottl, 1989; Fisher et al., 1990), and the western flank of the Mid-Atlantic Ridge (Langseth et al., 1984, 1992). These sites represent a wide range in sediment thickness and continuity, sediment type, crustal age, and basement topography, and they display a correspondingly wide range of hydrothermal conditions and processes, but our understanding of the processes remains only semiquantitative.

As a result of a series of coordinated surface-ship and submersible programs that began with a reconnaissance survey in 1988 (Davis et al., 1989), the eastern flank of the Juan de Fuca Ridge has become one of the most thoroughly studied ridge flanks. By providing critical hydrologic, geophysical, and geochemical samples and observations of three characteristic types of subseafloor fluid-flow systems that occur in simple form on this ridge flank, Leg 168 will allow a quantum step to be taken in understanding ridge-flank hydrothermal circulation and crustal evolution. The leg has taken advantage of recent ODP technological advances, including improvements to several tools that have greatly enhanced the success and the efficiency of the program's operations.

\section{STUDY AREA}

The Juan de Fuca Ridge is a seafloor spreading center that lies a few hundred kilometers off the coast of North America (Fig. 1; for reviews, see Johnson and Holmes, 1989; Davis and Currie, 1993). It has created the crust and lithosphere of the Juan de Fuca plate at a rate of about $29 \mathrm{~mm} / \mathrm{yr}$ (Figs. 2, 3). The topographic relief of the ridge (Figs. 4, 5 [back-pocket foldout], 6) produces a barrier to terrigenous turbidite sediment supplied from Pleistocene glacial sources along the continental margin, primarily at Queen Charlotte Sound, Juan de Fuca Strait, and the Grays Harbor and Columbia River estuaries. This situation has resulted in the accumulation of an onlapping layer of sediment that buries the eastern flank of the Juan de Fuca Ridge. This sedimented region known as Cascadia Basin extends from the base of the continental margin, where accretion of the sediment entering the Cascadia subduction zone begins, to within a few tens of kilometers of the ridge crest, where sediment laps onto crust that is at some locations younger than $1 \mathrm{Ma}$ (Figs. 4-6). Along the deformation front of the northern Cascadia accretionary prism, the sediment layer is 


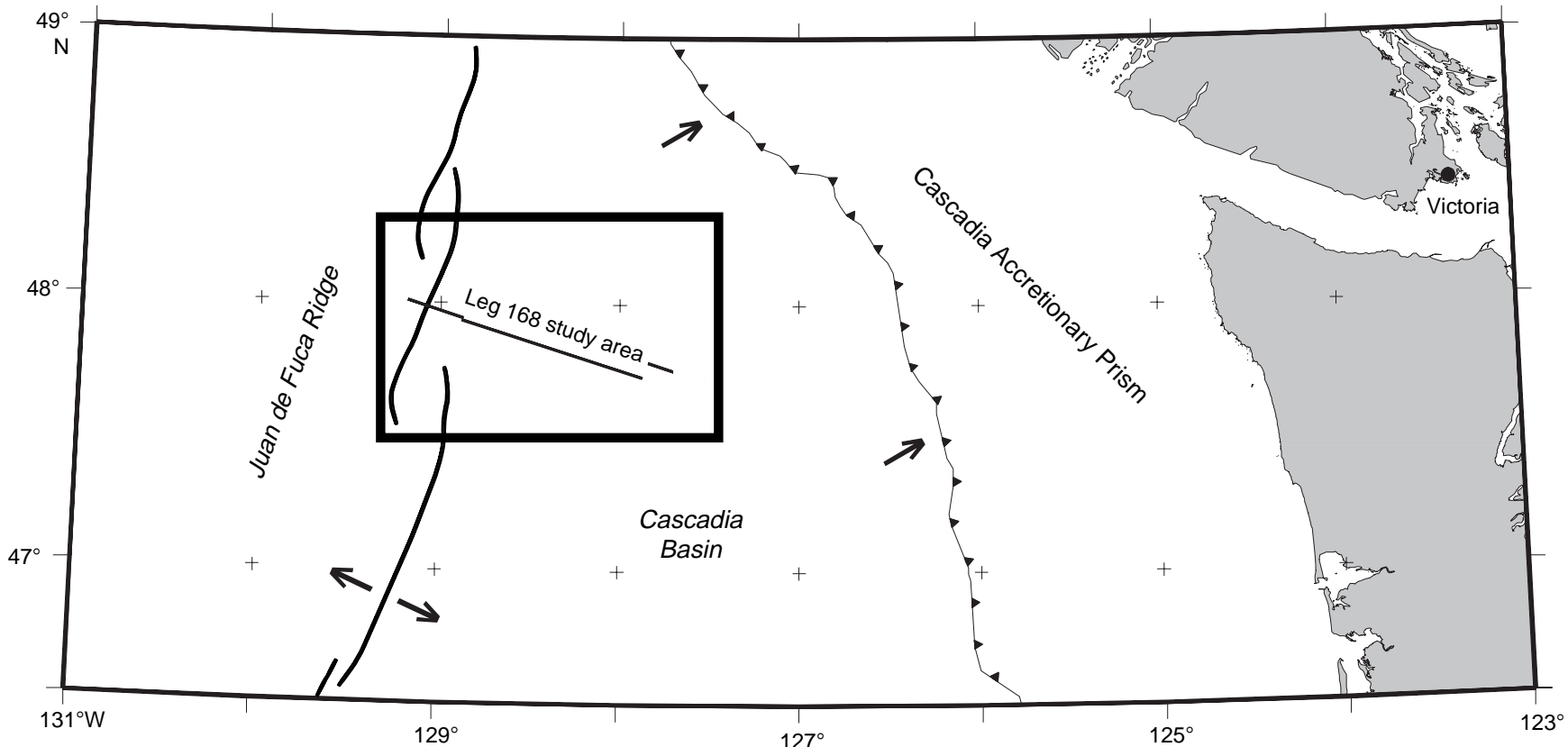

Figure 1. Tectonic setting of the Leg 168 drilling transect, including the axis of the Juan de Fuca Ridge and the deformation front of the Cascadia accretionary prism. The location of the seismic reflection profile shown in Figure 5 (back-pocket foldout) is indicated by the solid line, as is the area included in Figures 2 and 4.

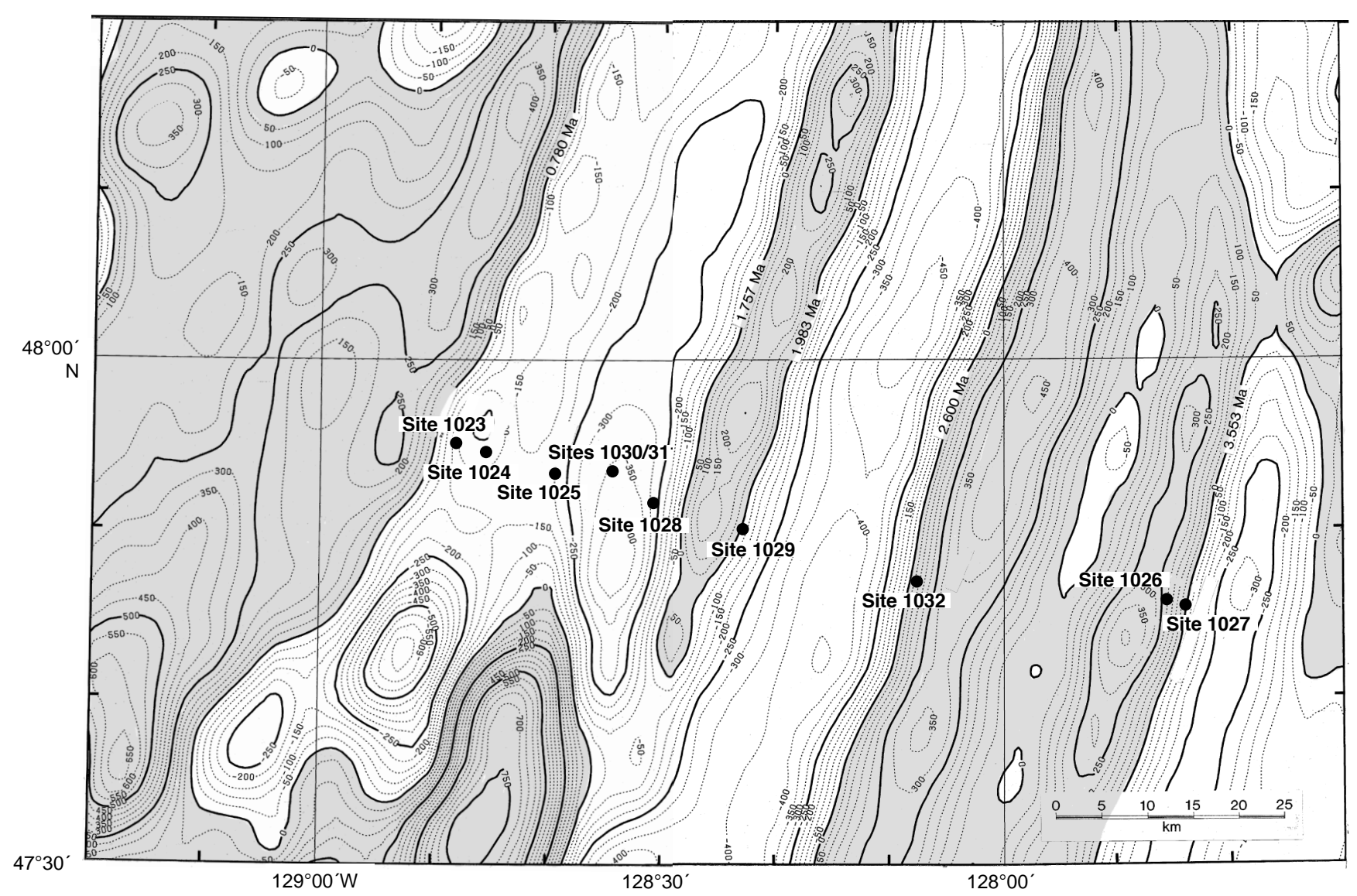

Figure 2. Magnetic anomalies over the eastern flank of the Juan de Fuca Ridge, with drilling sites and ages of magnetic polarity transitions shown. Positive anomalies are shaded (data from Currie et al., 1982). 


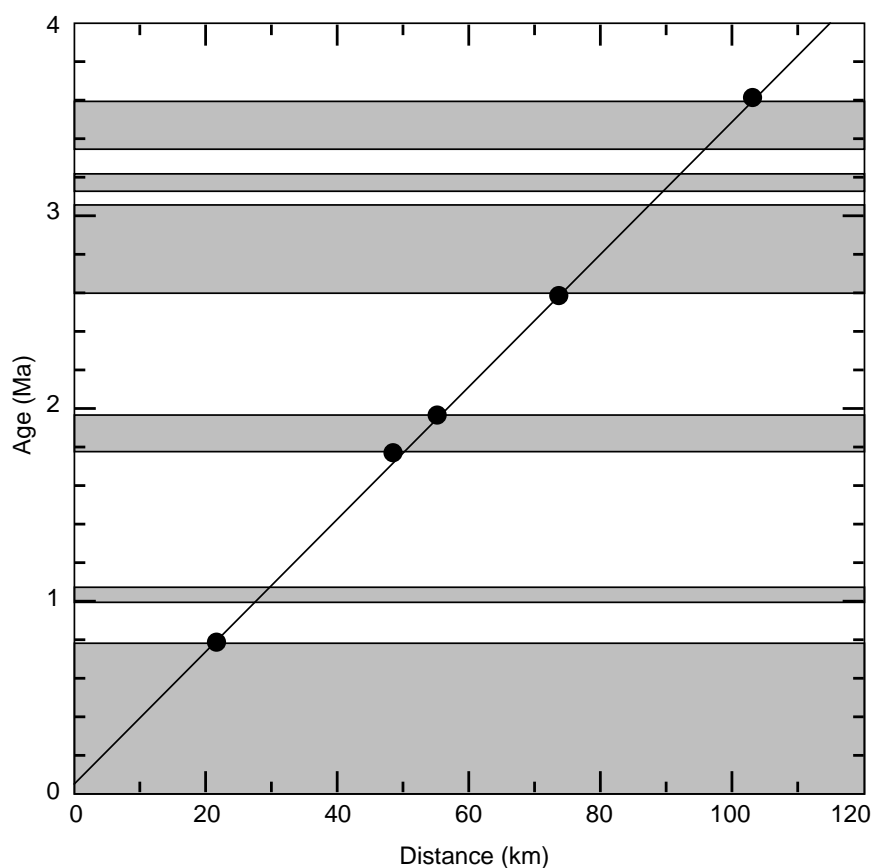

Figure 3. Ages of magnetic polarity transitions (from Cande and Kent, 1995) plotted against their distance from the axis of the Juan de Fuca Ridge (from Fig. 2). more than $3 \mathrm{~km}$ thick; in the northern part of the basin, the fill is sufficient to completely bury most of the relief of the igneous crust of the Juan de Fuca plate, with the exception of a few isolated volcanic cones and seamounts.

Beneath the nearly continuous, flat-lying sediment cover, local basement relief is dominated by linear ridges and troughs that were produced by normal faulting and variations in volcanic supply at the time the crust was created (e.g., Kappel and Ryan, 1986). The amplitude of this relief varies across the basin. At a point roughly $100 \mathrm{~km}$ east of the ridge axis, there is a fairly sharp boundary between areas of relatively smooth and rough basement relief. To the east, basement relief ranges typically from 300 to $700 \mathrm{~m}$, with ridges typically separated by 3 to $7 \mathrm{~km}$. Closer to the ridge crest, the crust is much smoother, with local relief typically only 100-200 m (Figs. 5 [back-pocket foldout], 6).

The region provides several ideal targets for studying hydrothermal processes. The sediments that blanket the eastern flank of the ridge provide a conveniently soft layer in which seafloor heat-flow measurements can be made and a relatively low-permeability, porous "filter" from which pore fluids can be extracted, such that patterns of hydrothermal fluid flow in the upper igneous crust can be inferred in considerable detail. The degree of sediment burial makes fluid venting relatively rare, but where it does occur it is highly focused and hence easily studied. The combination of water-column studies, direct submersible observations, and detailed seafloor heat-flow and pore-fluid geochemical measurements sited along closely spaced seismic reflection profiles has provided strong constraints on the directions and rates of fluid flow through the seafloor and on the thermal structure, patterns of fluid flow, and pore-fluid composition

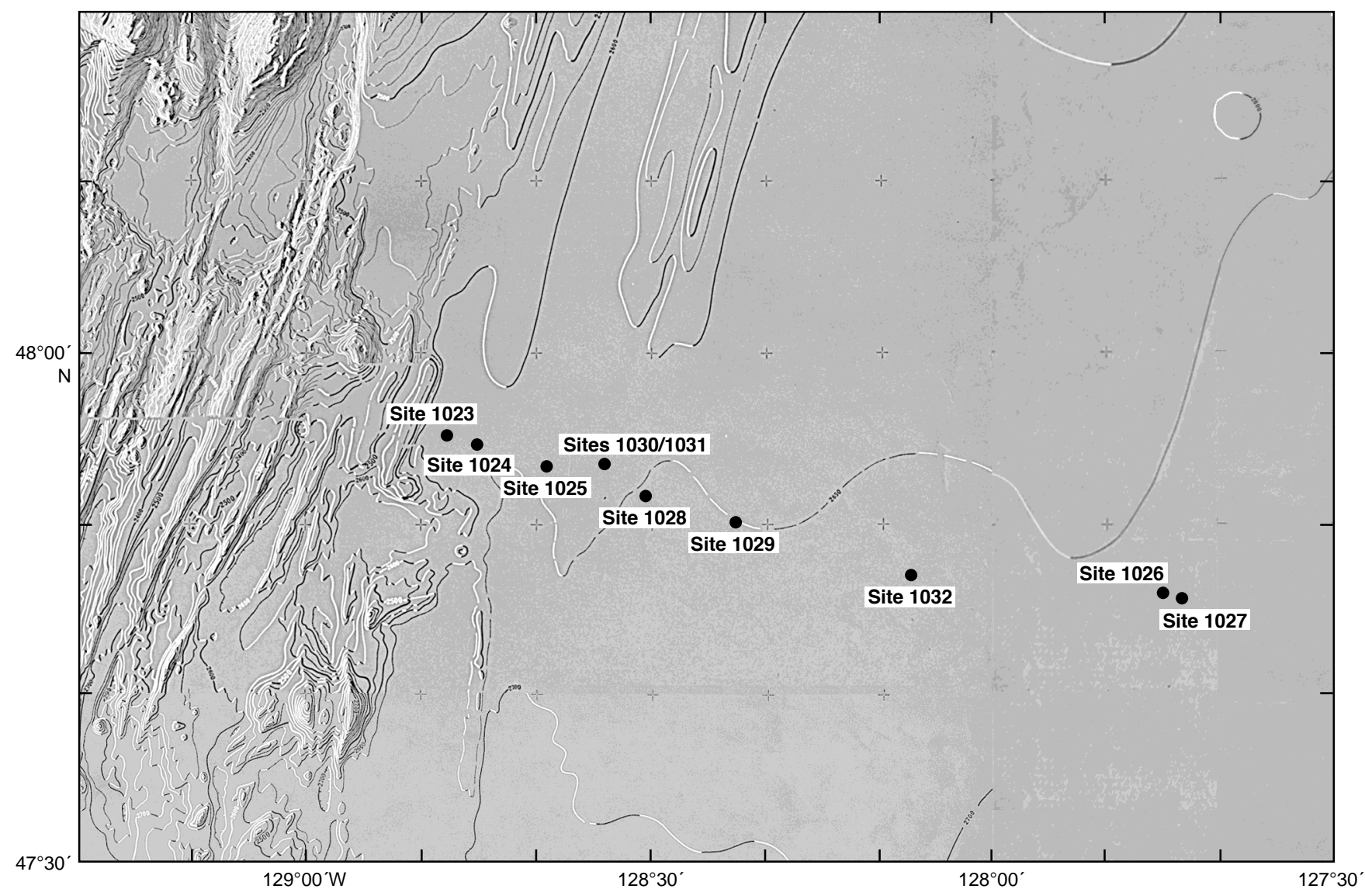

Figure 4. Bathymetry of the axis and eastern flank of the Juan de Fuca Ridge (same area as shown in Fig. 2; from Davis et al., 1987), with drilling site locations shown. Contours are shown at 20-m intervals in the vicinity of the ridge axis and at 50-m intervals in Cascadia Basin. 


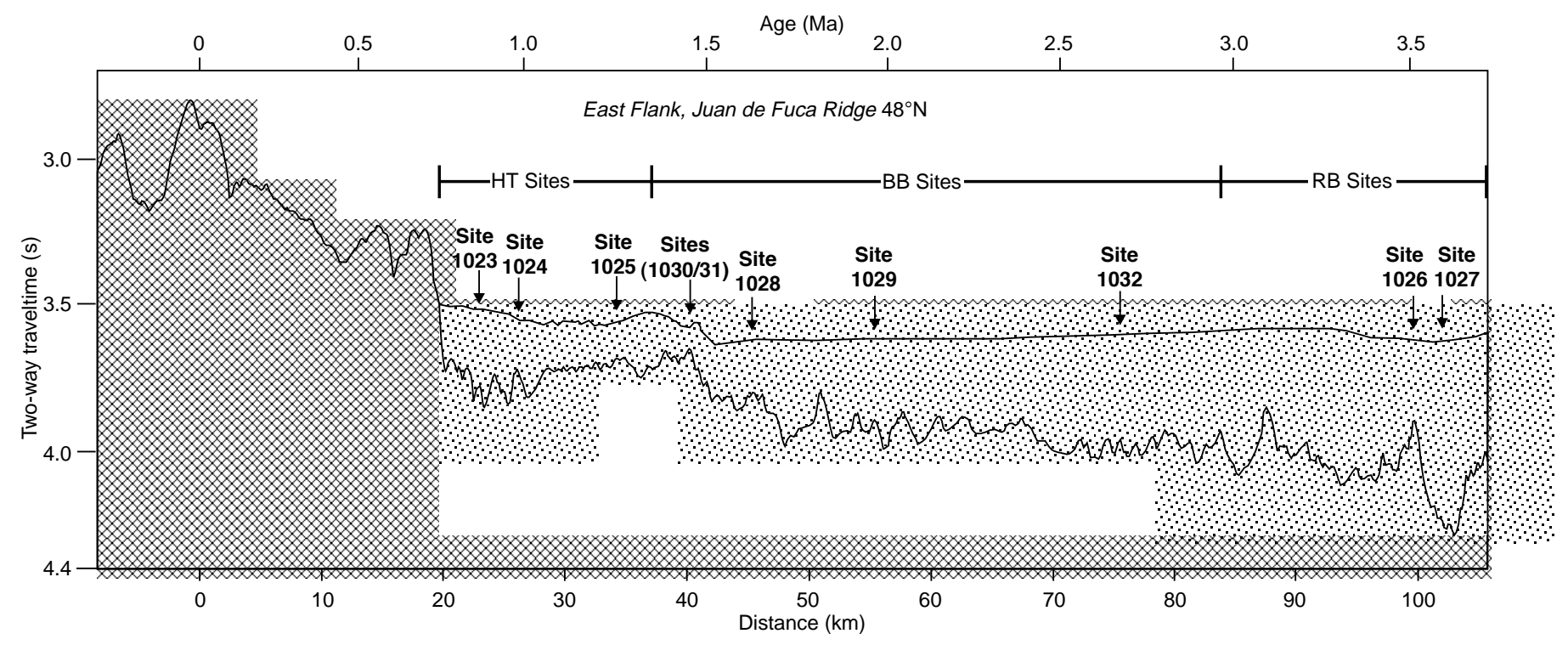

Figure 6. Basement topography (hatched area) and sediment cover (stippled area), eastern flank of the Juan de Fuca Ridge, derived from Figure 5 (back-pocket foldout). $\mathrm{HT}=$ Hydrothermal Transition; $\mathrm{BB}=$ Buried Basement; and RB = Rough Basement.

within the upper igneous crust (e.g., Davis et al., 1992b, 1997; Wheat and Mottl, 1994; M. Mottl, unpubl. data; Thomson et al., 1995). These studies formed the framework for the drilling program carried out during Leg 168.

Of particular interest were the remarkably simple examples of three general types of crustal fluid-flow regimes found on the eastern Juan de Fuca Ridge flank that became the focus of this drilling leg. These three type examples comprise (1) a transition zone between sediment-free (permitting open hydrothermal circulation) and sediment-covered (hydrologically sealed) igneous crust; (2) an area where rugged basement topography, large variations in sediment thickness, and small, isolated basement outcrops are inferred to exert a dominant influence on the pattern and rate of fluid flow within the upper igneous crust and through the seafloor into the water column; and (3) an area where a uniform and regionally continuous cover of sediments over unusually flat-lying basement prevents local advective heat loss and crust/ocean fluid exchange. Although the crust in which these examples occur is unusually young, similar situations can be found on many ridge flanks, and the lessons learned should be extremely valuable for understanding the fundamental nature and consequences of crustal fluid flow as it occurs throughout the world's oceans.

Figure 7 provides a perspective of this range of thermal and alteration environments on the eastern Juan de Fuca Ridge flank, where the basement topography, sediment thickness, heat flow, estimated and observed basement temperatures, and upper basement seismic velocities are plotted against distance from the ridge along part of the profile shown in Figure 6. A complete compilation of the heat-flow data and a summary of other primary data from the region are provided in the data report in Davis et al. (this volume). Details of the environment at each of the drilling sites are discussed below.

\section{SCIENTIFIC OBJECTIVES AND STRATEGY Summary of Objectives}

The primary objectives of ODP Leg 168 focused on exploring the causes and consequences of ridge-flank hydrothermal circulation by drilling a suite of relatively shallow holes that allowed observations of lateral gradients of temperature, pressure, fluid composition, and rock alteration. Stated in general terms, the objectives were to (1) determine the thermo-physical characteristics of hydrothermal circulation in the upper oceanic crust in off-axis settings as influenced by crustal topography, sediment cover, and permeability; (2) determine the sensitivity of crustal fluid composition to the age, temperature, and degree of sediment burial of the igneous crust; (3) examine the nature and fundamental causes of mineralogic and chemical alteration and the consequent physical consolidation of the igneous crust as functions of age and degree of sediment burial; and (4) improve constraints on the fluxes of heat and elements between the permeable igneous crust and the overlying ocean. The program was designed to address these questions in the true spirit of a field experiment, in which several hypotheses were to be critically tested with observations that could be made by drilling in each of the type areas as summarized below.

The specific drilling strategy adopted during Leg 168 involved a mixture of conventional drilling, coring, and reentry operations at each site. In many instances, the program represented a slight departure from traditional ODP operations, providing an efficient means by which all primary objectives, including the safe establishment of four cased reentry holes sealed with Circulation Obviation Retrofit Kit (CORK) hydrologic observatory installations, could be met during the 56 days allotted to the leg. Time was saved by reducing the total number of pipe trips, mainly by offsetting the drillship between neighboring sites without recovering the drill pipe.

An additional departure was made in the preparation of this volume by grouping the 10 individual sites (i.e., traditionally defined by the range for single-beacon acoustic navigation) into three operational "super sites" according to geographic area, represented process, and primary objectives as outlined above. These are (1) the Hydrothermal Transition Transect, (2) the Buried Basement Transect, and (3) the Rough Basement Transect. The organization of the volume reflects this grouping.

\section{Hydrothermal Transition Transect}

About $20 \mathrm{~km}$ east of the axis of the Endeavour segment of the Juan de Fuca Ridge, the elevated relief of the ridge crest plunges beneath the western edge of Cascadia Basin (Figs. 4, 5 [back-pocket 

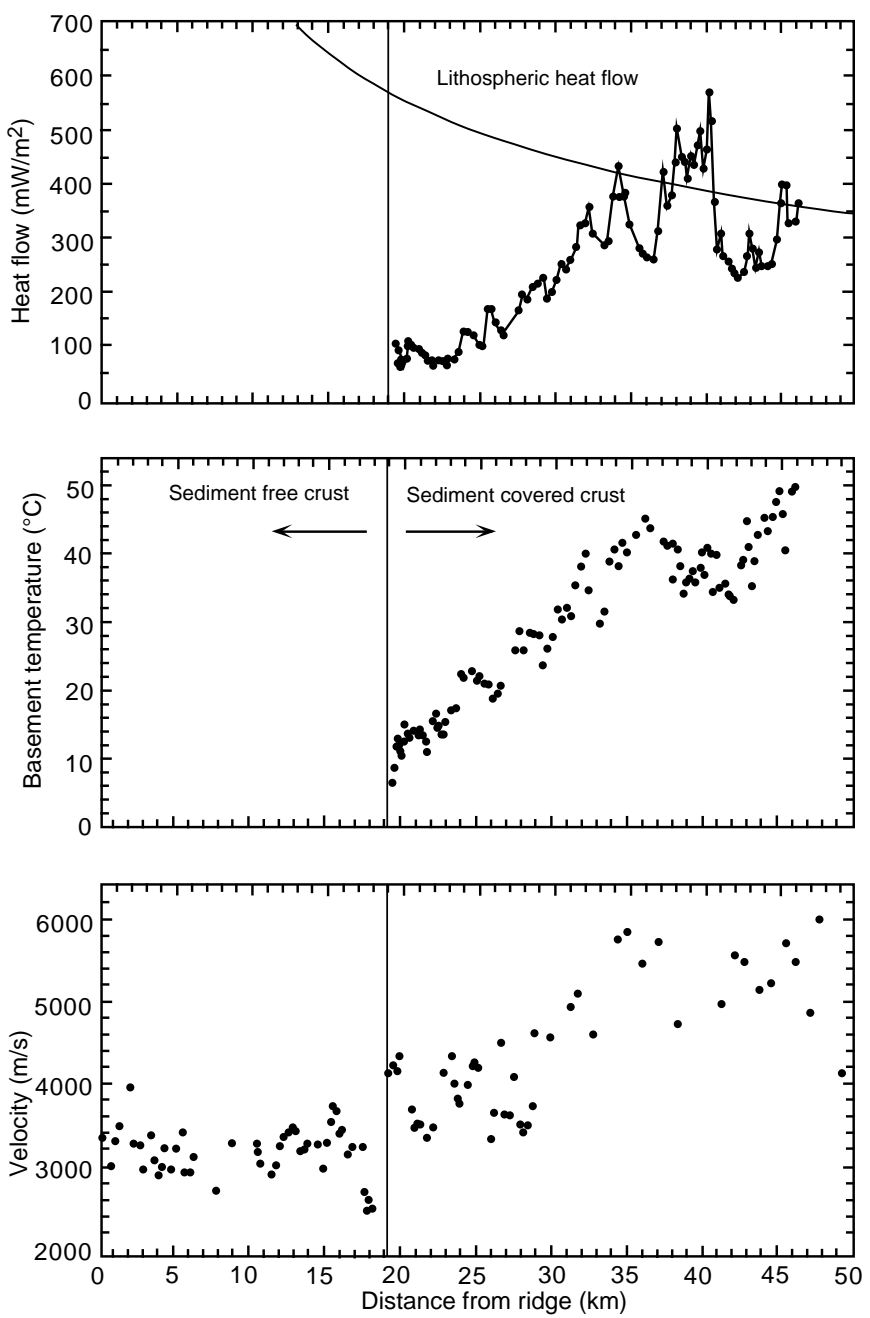

Figure 7. Heat flow (from Davis et al., this volume), estimated basement temperature, and upper basement seismic velocities (from Rohr, 1994) plotted as a function of distance from the axis of the Juan de Fuca Ridge. An estimate of the total lithospheric heat flow (Lister, 1977; Parsons and Sclater, 1977) is shown for comparison.

foldout], 6). A fundamental change in the nature of hydrothermal circulation occurs in this area. West of the edge of the abyssal plain turbidites, basement is covered by a relatively thin (less than $1 \mathrm{~m}$ to a few tens of meters), discontinuous veneer of hemipelagic sediment through which fluids can pass with little hydrologic impedance; whereas to the east, the igneous crust is thickly blanketed by turbidite sediments that create a hydrologic barrier. Heat flow and estimated upper crustal temperatures, seismic velocities in the upper crust, and estimates of basement pore-fluid compositions all show clear lateral gradients that are probably associated with the transition from open to sealed hydrothermal circulation (Fig. 7). Heat-flow values and estimated basement temperatures increase systematically to the east, away from the area of exposed basement (Davis et al., 1992b). Estimated temperatures in the upper igneous crust increase from less than $10^{\circ} \mathrm{C}$ near where basement rocks outcrop to about $40^{\circ}-45^{\circ} \mathrm{C} 20 \mathrm{~km}$ to the east. Over the same distance, the average heat flow increases from less than $15 \%$ to more than $80 \%$ of the value expected for the underlying lithosphere.

Basement pore-fluid compositions estimated from sediment porefluid studies (Wheat and Mottl, 1994) change from close to that of seawater near the outcrop to being strongly depleted in magnesium and enriched in calcium at a location $20 \mathrm{~km}$ to the east. Inferred chlorinities of the fluids in basement $20 \mathrm{~km}$ east of the point of burial are considerably higher than found in seawater. Part of the increased chlorinity may be caused by ongoing hydration reactions in the crust. This is consistent with the increase in basement temperature and with seismic data, which also reveal a systematic change. Interval velocities determined for the upper crustal seismic Layer $2 \mathrm{~A}$ increase from values that range from $3000-3500 \mathrm{~m} / \mathrm{s}$ to values exceeding $5000 \mathrm{~m} /$ s over the same spatial interval of about $20 \mathrm{~km}$ (Rohr, 1994). Although these velocities have been determined for a layer known to have strong vertical velocity gradients, they probably indicate a significant increase in velocities throughout Layer $2 \mathrm{~A}$. The increase is believed to indicate a decrease in porosity (e.g., Wilkens et al., 1991) and bulk modulus resulting from alteration. A similar magnitude of change occurs on other ridge flanks (e.g., Houtz and Ewing, 1976), although at a much slower rate, probably because the hydrologic isolation of the upper igneous crust is normally much more gradual.

To document the actual changes in basement-fluid temperatures and compositions, the physics of fluid flow, and the alteration of the crustal rocks, a transect of holes was drilled across this hydrothermal transition. Sites 1023, 1024, and 1025 (from west to east) comprise the Hydrothermal Transition Transect (Figs. 5 [back-pocket foldout], 6). Specific questions addressed along this transect included the following:

1. How does chemical and thermal transport take place over distances of $10-20 \mathrm{~km}$ in sediment-covered igneous crust? If there is a net horizontal transport of fluid, what is the rate?

2. What is the source and magnitude of the pressure gradient that drives the flow?

3. How do the changes in fluid chemistry and temperature with distance from sediment-free areas affect the nature of rock alteration?

4. What is the dominant factor responsible for the increase in upper crustal velocity?

5. Is there an accompanying decrease in sediment or basement permeability?

6. At what rate does crustal alteration take place?

It was anticipated that if relationships could be determined between basement temperature, fluid chemistry, and crustal alteration, then the results of studying this simple hydrothermal transition zone could be generalized to other ocean basins.

\section{Buried Basement Transect}

In a region spanning from $\sim 40$ to $100 \mathrm{~km}$ from the ridge crest, igneous basement is relatively smooth and continuously sedimented (Figs. 5 [back-pocket foldout], 6). A suite of parallel seismic lines running perpendicular to the ridge demonstrates that this character is continuous for at least $30 \mathrm{~km}$ along strike (Davis et al., 1992b). Because the sediment layer covering basement is so uniform and regionally extensive, the site provided a tempting target for sampling "equilibrium" basement and for determining accurately the level of total heat loss from young oceanic lithosphere. Local heat-flow variability normally associated with sediment thickness variations was expected to be small, and the closest basement outcrops through which undetected advective heat and chemical exchange could take place were originally thought to be sufficiently far away $(\sim 60-100 \mathrm{~km})$ to have an insignificant effect.

Accurate determination of the "normal" total rate of heat loss from oceanic lithosphere has been pursued for as long as marine heatflow measurements have been collected. Obtaining high-quality lithospheric heat-flow "calibration" data has been extremely difficult, however, because of the perturbing effects of hydrothermal circulation that are usually very difficult to avoid, particularly for young 
crust (e.g., Sclater et al., 1976). Many studies critically depend on knowing the relationship between lithospheric heat flow and age. The heat flow vs. age relationship allows determination of estimates of deep-rock thermal properties (e.g., Lister, 1977). It allows accurate estimation of global heat loss using the known global distribution of seafloor age (e.g., Williams and Von Herzen, 1974; Sclater et al., 1980). An accurate reference heat flow vs. age relationship allows the thermal anomalies associated with mantle plumes, asthenospheric convection, and widespread reheating events to be determined (e.g., Von Herzen et al., 1982, 1989). And, of course, it allows estimation of local and regional hydrothermal fluid budgets.

Conventional oceanographic heat-flow measurements were attempted in this otherwise ideal study area during site surveys, but shallow sandy layers prohibited probe penetration. Temperature and thermal conductivity data from ODP boreholes were intended to provide an accurate estimate of the regional basement temperature. We hoped that this information, combined with the well-determined depth to basement defined by seismic and drilling data and the knowledge that efficient lateral hydrothermal heat transport maintains an effectively isothermal sediment/basement surface, would provide an excellent estimate of the regional lithospheric flux to be made.

An equally important and fundamental objective of drilling in this continuously sedimented area was to provide intermediate samples of basement rocks and water along the overall transect from relatively fresh to hydrothermally altered oceanic crust. Based on the estimated total lithospheric heat flow predicted on the basis of age $(\sim 350 \mathrm{~mW} /$ $\left.\mathrm{m}^{2}\right)$, and the local average sediment thickness $(\sim 320 \mathrm{~m})$, the temperature at the top of basement at this site was expected to be as high as $80^{\circ} \mathrm{C}, 15-20 \mathrm{~K}$ higher than temperatures estimated at the rough basement site. This, and the known degree of hydrologic isolation, made sampling and measurements in the deep sediment section and basement in this area a high priority.

Sites 1028, 1029, 1030, 1031, and 1032 comprise the Buried Basement Transect. Sites 1030 and 1031, on the western edge of the Buried Basement Transect and just to the east of the Hydrothermal Transition Transect, are located where a buried basement ridge rises to within $40-50 \mathrm{~m}$ of the seafloor. The other Buried Basement Transect sites were drilled where the sediment layer over basement was $120-290 \mathrm{~m}$ thick.

\section{Rough Basement Transect}

Roughly $100 \mathrm{~km}$ east of the ridge axis, there is an abrupt change from the region of relatively smooth basement, typified by the Buried Basement Transect discussed above, to a region where the basement surface is much more rugged. In this region, basement topography comprises linear ridges and troughs produced by block faulting and by variations in volcanic supply at the time the seafloor was created, as well as off-axis, constructional volcanism. Local relief of 300 to $500 \mathrm{~m}$ between ridges and troughs is common, and major ridges are separated typically by 3-7 km (e.g., Figs. 5 [back-pocket foldout], 6). All of this relief is now buried by the turbidites of Cascadia Basin. The tops of two ridges lie a few tens to a few hundreds of meters below the sediment surface. At three locations along these ridges, small volcanic edifices rise above the sediment surface to form small, isolated basement outcrops (Fig. 8).

It has long been suggested that basement topography and local basement outcrops play a key role in seafloor hydrogeology by serving to enhance buoyancy-driven flow (e.g., Lowell, 1980; Hartline and Lister, 1981; Fisher et al., 1990; Fisher and Becker, 1995; Wang et al., 1997) and to focus flow from the igneous crust into the oceans (e.g., Lister, 1972; Davis and Becker, 1994). The simplicity of the local structure and the small size of the volcanic outcrops on this part of the eastern flank of the Juan de Fuca Ridge make the area an ideal target for seafloor studies. Results of the series of systematic surveys completed before Leg 168 established several aspects concerning fluid flow in the crust and discharge through the seafloor in this environment:

1. Fluid circulation within the upper oceanic crust is sufficiently vigorous to maintain relatively uniform temperatures at the sediment/ basement interface, despite variations of sediment thickness of more than a factor of 5 (Davis et al., 1992b, 1997).

2. In the few locations where samples could be obtained, basement-fluid compositions also appear locally homogeneous (Wheat and Mottl, 1994; M. Mottl, unpubl. data).

3. Fluids leak through the sediment "seal" above buried basement ridges at geochemically detectable rates $(<1$ to tens of millimeters per year) that are inversely proportional to the local sediment thickness (Davis et al., 1992b; Wheat and Mottl, 1994).

4. Fluids flow through the basement outcrops at rates sufficient to produce warm springs at the seafloor (M. Mottl, unpubl. data) and to generate detectable thermal, chemical, and light transmissivity anomalies in the water column (Thomson et al., 1995). The total advective heat loss is inferred to be great enough to cause the heat flow in the vicinity of the outcrops to be depressed below the level expected from this 3.5-Ma lithosphere (Davis et al., 1989).

5. Discharge through the outcrop has been sufficiently long-lived to allow significant hydrothermal precipitates to accumulate. Cores from the outcrop have recovered green clay, semilithified black ferromanganese crusts and layers, and reddish iron oxides in indurated sediment (M. Mottl, unpubl. data).

6 . The thermal structures of all three basement outcrops are fundamentally the same, allowing us to conclude that upflow and discharge are not only stable and long-lived but a general consequence of the permeability and temperature structures of what are referred to as permeable penetrators (Fig. 8).

Although the complete burial of the ridges and nearly complete burial of the outcrops in this area makes them exaggerated examples, they are representative of a general class of circulation that is present wherever the crustal topographic relief of mid-ocean ridge flanks is partially or completely filled in by sedimentation. An example of an "early" phase is the region of North Pond on the Mid-Atlantic Ridge flank studied by Langseth et al. (1992). A relic, fully buried example was probably intersected at Site 417 on the Mid-Atlantic Ridge flank (Donnelly et al., 1980). A highly focused and very active example was investigated at Site 858 during Leg 139 in the Middle Valley rift (Shipboard Scientific Party, 1992; Davis and Becker, 1994).

Examples of topographically influenced circulation within the upper igneous crust occur on the Costa Rica Rift flank (holes in the vicinity of and including Hole 504B; e.g., Langseth et al., 1988; Mottl, 1989; Fisher et al., 1990; Fisher and Becker, 1995), and possibly on the northern and southern flanks of the Galapagos spreading center (Green et al., 1981; Fisher and Becker, 1995). Again, the high degree of burial makes the Juan de Fuca Ridge flank an exaggerated example of topographically influenced fluid flow, but one that is ideally suited to the study carried out during Leg 168.

Whereas the general characteristics of fluid flow within the crust and through the seafloor in an environment like this are beginning to be understood, proper quantification of the hydrologic regime and elucidation of the consequences of fluid flow required drilling. With the array of holes completed during Leg 168, the following questions were addressed:

1. To what degree are basement fluids thermally and chemically homogenized by circulation in this environment?

2. What implications can be drawn about the bulk hydrologic transport properties of the upper crust from constraints gained from observations of lateral temperature, pressure, and compositional gradients? 

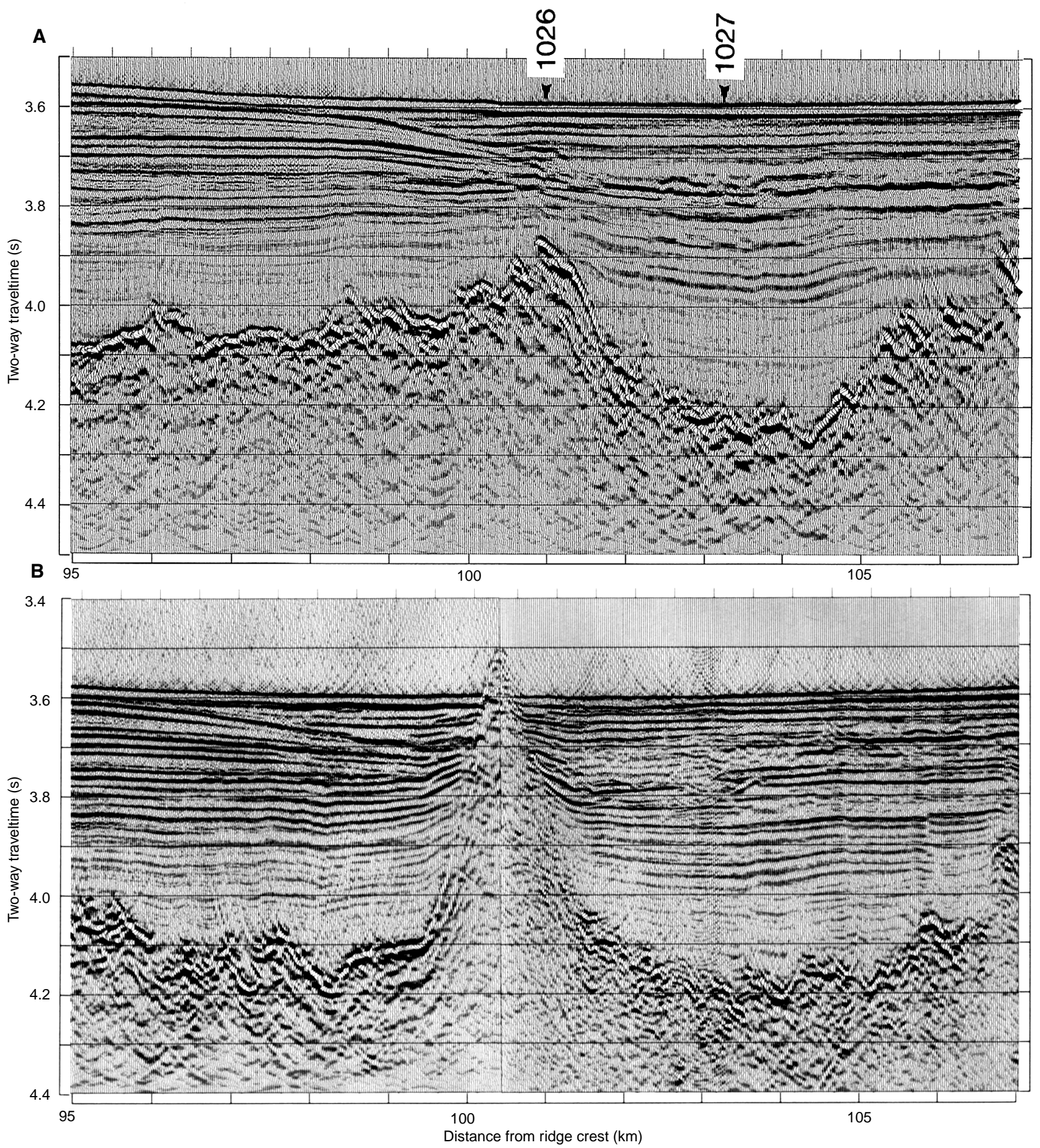

Figure 8. Seismic reflection profiles (A) across the buried ridge where Sites 1026 and 1027 are located and (B) across a basement edifice where basalt is exposed at the seafloor $7 \mathrm{~km}$ to the south. Data were collected using a 1.5-L $\left(90-\mathrm{in}^{3}\right)$ Generator-Injector gun source and a digital acquisition and processing system operated by the University of Bremen (see Davis et al., this volume, for details).

3. How is permeability distributed within upper basement?

4. To what degree has hydrothermal alteration of the crust proceeded at this 3.5-Ma site, and how has the alteration proceeded with time and burial history?

5. How have physical properties, namely seismic velocity and permeability, changed with alteration?
6. What are the nature and magnitude of the forces that drive fluid flow through the sediment section above basement ridges and through permeable penetrators, where basement is exposed at the seafloor?

7. What is the source of the fluids that vent through the seafloor at the outcrops? Do they simply come from the inferred homo- 
geneous basement "reservoir" regionally sealed beneath the sediments, or is there a component from a deeper source?

8. How are sediments chemically and physically affected by fluid seepage? Can a declining rate of seepage through the sediment section be tracked through the history of burial?

9. What is the nature of recharge? Is seawater supplied to the crust solely by regional diffuse flow through the sediments away from basement highs, or do some fluids enter the crust via local or distant basement pathways?

Sites 1026 and 1027 comprise the Leg 168 Rough Basement Transect, with Site 1026 located over a basement ridge and Site 1027 located over a basement trough about $2.2 \mathrm{~km}$ to the east.

\section{PRELIMINARY SUMMARY OF DRILLING, CORING, AND DOWNHOLE MEASUREMENTS}

\section{Hydrothermal Transition Transect}

Drilling at all three Hydrothermal Transition sites recovered similar sequences of rhythmic sand and silt turbidites (lithologic Unit I). Most individual beds are a few centimeters to $1 \mathrm{~m}$ thick and are interbedded with hemipelagic mud typically tens of centimeters to $1 \mathrm{~m}$ thick. These sequences were deposited above an interval of turbiditefree hemipelagic mud, ranging from 3 to $20 \mathrm{~m}$ thick (Unit II), that was deposited directly over igneous basement. The total thickness of Unit I is $190 \mathrm{~m}, 150 \mathrm{~m}$, and $87 \mathrm{~m}$ at Sites 1023, 1024, and 1025, respectively. Calcareous nannofossils were sampled from hemipelagic layers and show the following age correlations: base of Emiliania huxleyi $(\sim 0.28 \mathrm{Ma})$ at roughly 43 meters below seafloor (mbsf) (Site 1023), $30 \mathrm{mbsf}$ (Site 1024), and $34 \mathrm{mbsf}$ (Site 1025); top of Pseudoemiliania lacunosa ( 0.46 Ma) at the base of sediments, $192.46 \mathrm{mbsf}$, at Site 1023. Site 1025 does not contain P. lacunosa, thus the basal sediments are $<0.46 \mathrm{Ma}$. Site 1024 contains the Brunhes/Matuyama magnetic polarity reversal $(0.78 \mathrm{Ma})$ at $166.2 \mathrm{mbsf}$. Basement ages of Sites 1023 to 1025 estimated from sea-surface magnetic anomalies are $0.86,0.97$, and $1.24 \mathrm{Ma}$ (Table 1), which indicate that sedimentation did not begin for several thousand years after basement formation.

Basement was intersected at 192.8, 167.8, and $97.5 \mathrm{mbsf}$ in Holes 1023A, 1024B, and 1025B, respectively (Table 1). The extended core barrel $(\mathrm{XCB})$ coring system cored $1 \mathrm{~m}$ of basement in Holes $1023 \mathrm{~A}, 1024 \mathrm{~B}$, and 1025B and recovered from six to 16 unoriented pieces of fragmented pillow basalt. Basement was also recovered from reentry Holes $1024 \mathrm{C}$ and $1025 \mathrm{C}$. Rotary core barrel (RCB) coring in Hole $1024 \mathrm{C}$ penetrated only $2 \mathrm{~m}$ and produced $6 \%$ recovery, whereas coring in reentry Hole $1025 \mathrm{C}$ extended from $106.1 \mathrm{mbsf}$ to $147.2 \mathrm{mbsf}$, and recovered $36.9 \%$.

Recovery from the XCB holes yielded many basalt pieces having thin unaltered glass rims. Phenocryst contents (plagioclase, olivine, and clinopyroxene) vary from $1 \%-2 \%$ in the basalt from Hole $1023 \mathrm{~A}$ to $<1 \%$ in the aphyric basalt from Holes $1024 \mathrm{~B}$ and 1025B. All of the basalt is vesicular ( $<1 \%$ vesicles; diameters $<1 \mathrm{~mm}$ ). Two types of volcanic units were identified from RCB coring of the reentry holes: pillow lava and massive basalt. Pillow basalts are present at the top of basement at all three Hydrothermal Transition sites. A succession of massive basalts (the total recovery from Hole 1025C) occurs structurally below the Hole 1025B pillows. Rare glass rims (separated by $\sim 1-15 \mathrm{~m}$ ) occur in the massive basalt units. Phenocryst contents are $<1 \%$ plagioclase plus clinopyroxene phenocrysts in the aphyric basalts sampled in Hole $1024 \mathrm{C}$ and the massive basalt from Hole $1025 \mathrm{C}$. The plagioclase phenocrysts range in size to as much as $5 \mathrm{~mm}$ long, whereas mafic phenocrysts are generally $\leq 1 \mathrm{~mm}$ in diameter. The pillow basalts have $<1 \%$ vesicles. The massive basalts have variable vesicularity, up to $12 \%$, and are moderately altered (5\%-25\%).
Whole-rock major element analyses show the basalts from Site 1024 to be low-potassium tholeiites with magnesium numbers (Mg\#) of 60-62, whereas those from Site 1025 are ferrobasalts $(\mathrm{Mg \#}=46-$ 49) having $\mathrm{TiO}_{2}$ equal to 2.43 to 2.70 wt. $\%$ and $\mathrm{Fe}_{2} \mathrm{O}_{3}$ equal to 14.50 to 15.91 wt.\% (with all iron calculated as $\mathrm{Fe}_{2} \mathrm{O}_{3}$ ). These latter rocks are among the most fractionated rocks known from the Endeavour segment of the Juan de Fuca Ridge.

All of the basement rocks from Sites 1023, 1024, and 1025 exhibit alteration, which is manifest in several ways and varies between sites. The presence of fresh olivines in Hole 1023A indicates that these samples have undergone the least amount of alteration. In contrast to Hole 1023A, practically all olivines from Site 1025 are completely replaced by a mixture of clay minerals (primarily saponite with some celadonite), minor carbonate, and rare talc and chlorite/smectite. Sample interiors vary from fresh (defined as having <2\% replacement by alteration minerals) in most of the pillows to slightmoderate (5\%-25\% alteration minerals) in the massive ferrobasalts.

Many pieces from Site 1024 contain centimeter-scale alteration halos just inside their outer surface. In hand specimen these halos have orange, yellow, and dark green material filling the vesicles. Microscopic observations suggest that these vesicle fillings include celadonite, saponite, and iron oxyhydroxides. Halos are rare in rocks from Hole 1023A and Site 1025.

Nearly all basement samples from Sites 1023, 1024, and 1025 possess incomplete clay coatings on their outer surfaces. The clay minerals are most frequently light blue to blue-green in hand specimen and have X-ray diffractograms typical of trioctahedral smectites. In nearly all of the basement samples from Sites 1023, 1024, and 1025, the vesicles (excluding those within alteration halos) are completely lined by a fine-grained blue clay, which is probably the same as that observed on the sample surfaces. In microscopic sections, this mineral is identified as saponite. Some basement samples from Sites 1023, 1024, and 1025 exhibit zeolites associated with the blue clay mineral on rock surfaces and within vesicles. Pyrite occurs as a trace mineral associated with saponite on many basement pieces and inside vesicles from all the Hydrothermal Transition sites. Several vein types occur at Site 1025; 111 veins were logged in Hole 1025C , as follows: clay (90 veins); clay + talc (10); clay + carbonate (6); clay + pyrite (1); talc (1); and quartz + clay (3). Most veins are $\leq 1 \mathrm{~mm}$ wide.

Basalts from the Hydrothermal Transition Transect illustrate progressive changes in alteration intensity related to variations in lithology and to increasing basement temperature from Site 1023 to Site 1024 to Site 1025 . Higher basement temperatures and coarser grain sizes combine to produce larger degrees of hydrothermal alteration, from a fraction of $1 \%$ in aphanitic pillow basalts at $15.5^{\circ} \mathrm{C}$ to as much as $25 \%$ alteration in fine-grained massive basalts in basement that is $38.2^{\circ} \mathrm{C}$ at the basement/sediment interface. No alteration effects were observed that require temperatures to have been higher than those prevailing today.

Methane, the dominant volatile hydrocarbon gas in the cored sediments, shows a strong negative correlation with pore-water sulfate concentrations at all sites. Sedimentary organic matter is low in organic carbon and has $\mathrm{C} / \mathrm{N}$ ratios that indicate a predominately marine origin. The organic matter is hydrogen poor, reflecting selective degradation of less stable marine organic compounds.

The composition of pore water at the three sites shows clear indications of reaction and diffusion in the sediment section. Vertical advection was evident only in Hole 1025B, where slow upward seepage of water was indicated by a systematic variation in profiles of $\mathrm{Ca}$, $\mathrm{Mg}$, and alkalinity. Some degree of super-hydrostatic pressure in basement at this site was also suggested by the presence of discharge from Hole $1025 \mathrm{C}$, which was drilled through the sediments and about $5 \mathrm{~m}$ into upper basement. This discharge was seen with the vibrationisolated television camera at the time of reentry with the $10 \Omega$-in casing string. 
Table 1. Summary of selected drilling and measurement results from ODP Leg 168.

\begin{tabular}{|c|c|c|c|c|c|c|c|c|c|c|c|c|c|c|}
\hline \multirow[b]{2}{*}{ Hole } & \multirow[b]{2}{*}{ Latitude } & \multirow[b]{2}{*}{ Longitude } & \multicolumn{2}{|c|}{$\begin{array}{l}\text { Depth to Basement } \\
\text { Top }^{\mathrm{a}}\end{array}$} & \multicolumn{2}{|c|}{ Basement Age $^{\mathrm{b}}$} & \multirow{2}{*}{$\begin{array}{l}\text { Distance from } \\
\text { ridge axis } \\
(\mathrm{km})\end{array}$} & \multirow{2}{*}{$\begin{array}{c}\text { Thermal } \\
\text { gradient }{ }^{\mathrm{c}} \\
(\mathrm{K} / \mathrm{m})\end{array}$} & \multirow[b]{2}{*}{$\begin{array}{l}\text { Heat flow } \\
\left(\mathrm{mW} / \mathrm{m}^{2}\right)\end{array}$} & \multirow{2}{*}{$\begin{array}{l}\text { Basement } \\
\text { temperature } \\
\left({ }^{\mathrm{c}} \mathrm{C}\right)\end{array}$} & \multicolumn{4}{|c|}{ Pore-fluid chemistry just above basement ${ }^{\mathrm{d}}$} \\
\hline & & & $\begin{array}{c}\text { Drillers' } \\
(\mathrm{mbsf})\end{array}$ & $\begin{array}{c}\text { Curated } \\
\text { (mbsf) }\end{array}$ & $\begin{array}{l}\text { Magnetic } \\
\text { (Ma) }\end{array}$ & Geologic & & & & & $\begin{array}{l}\text { Chlorinity } \\
(\mathrm{mmol} / \mathrm{kg})\end{array}$ & $\begin{array}{c}\mathrm{SO}_{4} \\
(\mathrm{mmol} / \mathrm{kg})\end{array}$ & $\underset{(\mathrm{mmol} / \mathrm{kg})}{\mathrm{Mg}}$ & $\begin{array}{c}\mathrm{Ca} \\
(\mathrm{mmol} / \mathrm{kg})\end{array}$ \\
\hline $1023 \mathrm{~A}$ & $47^{\circ} 55.040^{\prime} \mathrm{N}$ & $128^{\circ} 47.529^{\prime} \mathrm{W}$ & 192.0 & 192.8 & 0.860 & Quaternary & 22.360 & 0.071 & 84 & 15.5 & 542.1 & 24.2 & 47.2 & 11.5 \\
\hline $\begin{array}{l}1024 \mathrm{~A} \\
1024 \mathrm{~B} \\
1024 \mathrm{C}\end{array}$ & $\begin{array}{l}47^{\circ} 54.522^{\prime} \mathrm{N} \\
47^{\circ} 54.274^{\prime} \mathrm{N} \\
47^{\circ} 54.531^{\prime} \mathrm{N}\end{array}$ & $\begin{array}{l}128^{\circ} 44.975^{\prime} \mathrm{W} \\
128^{\circ} 45.132^{\prime} \mathrm{W} \\
128^{\circ} 45.005^{\prime} \mathrm{W}\end{array}$ & $\begin{array}{l}\overline{168.0} \\
151.7\end{array}$ & $\overline{167.8}$ & $\begin{array}{l}0.971 \\
0.970 \\
0.970\end{array}$ & $\begin{array}{l}\text { Quaternary } \\
\text { Quaternary } \\
\text { Quaternary }\end{array}$ & $\begin{array}{l}25.674 \\
25.624 \\
25.634\end{array}$ & $\frac{\overline{-} 125}{-}$ & $\overline{146}$ & $\overline{22.8}$ & $\overline{540.0}$ & $\overline{24.3}$ & $\overline{42.5}$ & $\overline{16.4}$ \\
\hline $\begin{array}{l}1025 \mathrm{~A} \\
1025 \mathrm{~B} \\
1025 \mathrm{C}\end{array}$ & $\begin{array}{l}47^{\circ} 53.247^{\prime} \mathrm{N} \\
47^{\circ} 52.998^{\prime} \mathrm{N} \\
47^{\circ} 53.247^{\prime} \mathrm{N}\end{array}$ & $\begin{array}{l}128^{\circ} 38.920^{\prime} \mathrm{W} \\
128^{\circ} 39.052^{\prime} \mathrm{W} \\
128^{\circ} 38.919^{\prime} \mathrm{W}\end{array}$ & $\begin{array}{r}\overline{97.5} \\
101.0\end{array}$ & $\overline{97.5}$ & $\begin{array}{l}1.237 \\
1.236 \\
1.237\end{array}$ & $\begin{array}{l}\text { Quaternary } \\
\text { Quaternary } \\
\text { Quaternary }\end{array}$ & $\begin{array}{l}33.559 \\
33.540 \\
33.561\end{array}$ & $0 . \overline{375}$ & $\overline{443}$ & $\overline{38.6}$ & $5 \overline{47.0}$ & $\overline{26.7}$ & $\overline{27.3}$ & $\overline{36.4}$ \\
\hline $\begin{array}{l}1026 \mathrm{~A} \\
1026 \mathrm{~B}\end{array}$ & $\begin{array}{l}47^{\circ} 45.757^{\prime} \mathrm{N} \\
47^{\circ} 45.759^{\prime} \mathrm{N}\end{array}$ & $\begin{array}{l}127^{\circ} 45.552^{\prime} \mathrm{W} \\
127^{\circ} 45.552^{\prime} \mathrm{W}\end{array}$ & $2 \overline{47} .1$ & - & $\begin{array}{l}3.511 \\
3.511\end{array}$ & $\begin{array}{l}\text { Pliocene } \\
\text { Pliocene }\end{array}$ & $\begin{array}{l}101.047 \\
101.046\end{array}$ & 0.242 & $\underline{328}$ & 61.4 & 562.6 & 1.6 & 35.5 & 10.2 \\
\hline $\begin{array}{l}1026 \mathrm{~B} \text { open borehole } \\
1026 \mathrm{C} \\
\text { Baby Bare springs }\end{array}$ & $47^{\circ} 46.261^{\prime} \mathrm{N}$ & $127^{\circ} 45.186^{\prime} \mathrm{W}$ & 228.9 & 228.9 & 3.516 & Pliocene & 101.192 & 0.259 & 345 & $\begin{array}{l}63.8 \\
61.7 \\
25.0\end{array}$ & $\begin{array}{l}552.5 \\
551.3 \\
554.4\end{array}$ & $\begin{array}{l}17.0 \\
14.4 \\
17.8\end{array}$ & $\begin{array}{l}2.2 \\
4.6 \\
0.0\end{array}$ & $\begin{array}{l}56.2 \\
65.7 \\
55.2\end{array}$ \\
\hline $\begin{array}{l}1027 \mathrm{~A} \\
1027 \mathrm{~B} \\
1027 \mathrm{C} \\
1027 \mathrm{C} \\
1027 \mathrm{C}\end{array}$ & $\begin{array}{l}47^{\circ} 45.412^{\prime} \mathrm{N} \\
47^{\circ} 45.412^{\prime} \mathrm{N} \\
47^{\circ} 45.387^{\prime} \mathrm{N} \\
\text { Top of diabase sill } \\
\text { Base of diabase sill }\end{array}$ & $\begin{array}{l}127^{\circ} 43.854^{\prime} \mathrm{W} \\
127^{\circ} 43.853^{\prime} \mathrm{W} \\
127^{\circ} 43.867^{\prime} \mathrm{W}\end{array}$ & $\begin{array}{l}- \\
6 \overline{13} .7 \\
575.5 \\
590.7\end{array}$ & $\begin{array}{l}\overline{-} \\
6 \overline{13.8} \\
584.8 \\
591.6\end{array}$ & $\begin{array}{l}3.586 \\
3.586 \\
3.586\end{array}$ & $\begin{array}{l}\text { Pliocene } \\
\text { Pliocene } \\
\text { Pliocene }\end{array}$ & $\begin{array}{l}103.256 \\
103.258 \\
103.255\end{array}$ & $\underline{0.103}$ & $\underline{135}$ & $\overline{62.8}$ & $\overline{\overline{5}} \overline{-}$ & $\frac{\overline{-}}{17.5}$ & $\overline{\overline{4}}_{4.5}$ & 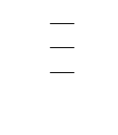 \\
\hline $1028 \mathrm{~A}$ & $47^{\circ} 51.479^{\prime} \mathrm{N}$ & $128^{\circ} 30.289^{\prime} \mathrm{W}$ & 132.5 & 132.5 & 1.615 & Quaternary & 44.778 & 0.373 & 457 & 50.5 & 549.0 & 15.0 & 16.0 & 40.4 \\
\hline $1029 \mathrm{~A}$ & $47^{\circ} 49.901^{\prime} \mathrm{N}$ & $128^{\circ} 22.597^{\prime} \mathrm{W}$ & 219.5 & 220.1 & 1.952 & Pliocene & 54.782 & 0.258 & 341 & 58.7 & 548.0 & 17.7 & 12.7 & 54.5 \\
\hline $\begin{array}{l}1030 \mathrm{~A} \\
1030 \mathrm{~B}\end{array}$ & $\begin{array}{l}47^{\circ} 53.847^{\prime} \mathrm{N} \\
47^{\circ} 53.847^{\prime} \mathrm{N}\end{array}$ & $\begin{array}{l}128^{\circ} 33.711^{\prime} \mathrm{W} \\
128^{\circ} 33.711^{\prime} \mathrm{W}\end{array}$ & $\overline{46.9}$ & - & $\begin{array}{l}1.434 \\
1.434\end{array}$ & $\begin{array}{l}\text { Quaternary } \\
\text { Quaternary }\end{array}$ & $\begin{array}{l}39.407 \\
39.407\end{array}$ & $0 . \overline{817}$ & $9 \overline{56}$ & $\overline{40.1}$ & $5 \overline{59} .0$ & $\overline{22.3}$ & $\overline{5.7}$ & $\overline{57.1}$ \\
\hline $1031 \mathrm{~A}$ & $47^{\circ} 53.400^{\prime} \mathrm{N}$ & $128^{\circ} 33.970^{\prime} \mathrm{W}$ & 41.3 & 41.3 & 1.432 & Quaternary & 39.347 & 0.931 & 1087 & 40.4 & 557.7 & 23.4 & 4.7 & 60.3 \\
\hline $1032 \mathrm{~A}$ & $47^{\circ} 46.773^{\prime} \mathrm{N}$ & $128^{\circ} 07.341^{\prime} \mathrm{W}$ & 291.2 & 290.3 & 2.621 & Pliocene & 74.635 & 0.223 & 299 & 57.1 & 555.4 & 16.8 & 2.8 & 61.4 \\
\hline Bottom seawater & & & & & & & & & & 1.8 & 542.0 & 28.0 & 52.7 & 10.2 \\
\hline
\end{tabular}

${ }^{a}$ Depths to basement estimated by Leg 168 drillers are based on changes in drilling parameters (rate of penetration, torque, and core recovery), whereas depths to basement based on standard curatorial practice are based on the assumption that the recovery originated from the top of the cored interval.

${ }^{b}$ Estimated basement ages based on seafloor magnetics data were calculated by assigning absolute ages to individual magnetic boundaries and then linearly interpolating between magnetic boundaries as a function of distance.

"Thermal gradient and heat flow are based on sediment temperatures and thermal conductivity data. Estimated temperatures at the top of basement based on sediment temperatures extrapolated to the depth of the sediment/basement contact.

Pore-water geochemical measurements are core samples closest to the sediment/basement contact.

${ }^{e}$ Hole 1026B borehole data are based on samples and measurements made in open hole with the water-sampling temperature probe (WSTP) and temperature coring shoe. Pore-water values are the means of measurements made on two primary fluid samples collected during back-to-back WSTP deployments.

Data are from warm springs on the Baby Bare seamount outcrop (previously unpublished data) 


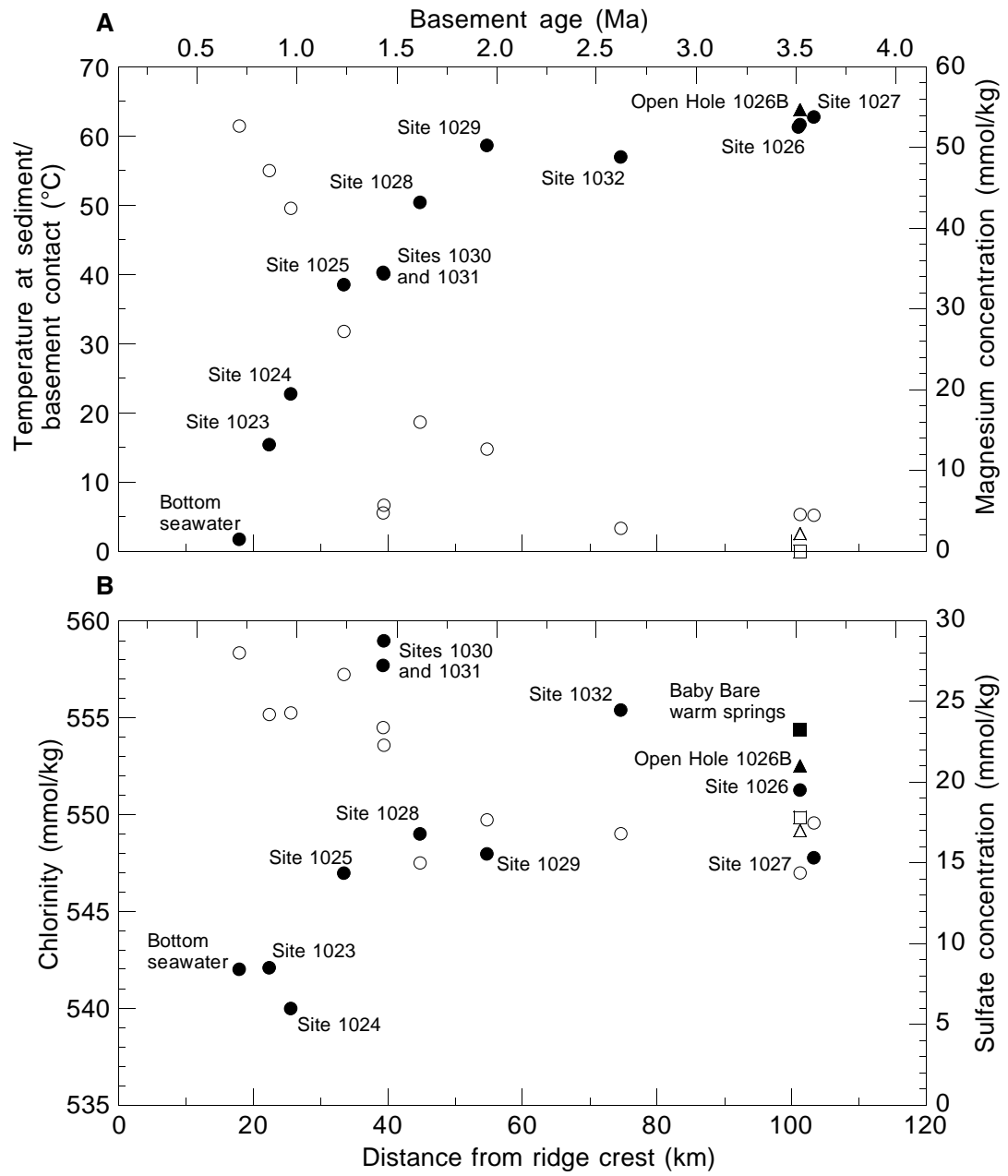

Figure 9. Summary plots of basement temperatures and pore-water compositions vs. distance from the ridge crest. Leg 168 pore-water and bottom-water values (circles), Baby Bare warm spring data (squares), and open-hole data from Hole 1026B (triangles) are included for comparison. A. Temperature (solid symbols) and magnesium concentration (open symbols). B. Chlorinity (solid symbols) and sulfate concentration (open symbols).

Basement-water compositions, inferred from pore-fluid compositions in basal sediments, revealed systematic changes with increasing temperature and distance from outcrop in some elemental concentrations (Table 1; Fig. 9). Changes were most apparent in magnesium and calcium, which are particularly reactive in basement. Concentrations in samples from Hole 1023A were $47 \mathrm{mmol} / \mathrm{kg} \mathrm{Mg}$ and 11 $\mathrm{mmol} / \mathrm{kg} \mathrm{Ca}$, only slightly changed from seawater at $53 \mathrm{mmol} / \mathrm{kg}$ $\mathrm{Mg}$, and $10 \mathrm{mmol} / \mathrm{kg} \mathrm{Ca}$. At Site 1025, the site farthest from outcrop, $\mathrm{Mg}$ had fallen to $28 \mathrm{mmol} / \mathrm{kg}$, and Ca had risen to $37 \mathrm{mmol} / \mathrm{kg}$. Chlorinity values were perhaps most interesting. The commonly observed increase from present-day seawater values of $542 \mathrm{mmol} / \mathrm{kg}$ at the seafloor to elevated values of relic Pleistocene water at depths of a few tens of meters below seafloor was seen in all three cored holes. Chlorinity values decreased at greater depths, however, to values identical to present-day (postglacial) seawater in Holes 1023A and 1024B and to only a slightly elevated value $(547 \mathrm{mmol} / \mathrm{kg})$ in Hole $1025 \mathrm{~B}$. A simple interpretation of these low-chlorinity values is that the water has a residence time in basement of only a few thousand years, even at the site most distant from outcrop.

Sediment physical properties along the Hydrothermal Transition Transect generally reflect increasing compaction with depth and variations in sand, silt, and clay contents. Finer grained sediments exhibit a consistent decrease in porosity and increase in bulk density with depth, whereas coarser grained units do not. Sediment thermal con- ductivities are dominated by differences in porosity, which are influenced by sand content and, in the finer grained parts of the section, by compaction. Sediment magnetic susceptibility, measured continuously with the multisensor track (MST), permitted identification of sandy layers in cores before they were split and facilitated the collection of whole-round samples for later permeability and thermal conductivity analyses.

Temperatures were measured in the sediment section with the goal of obtaining accurate determinations of temperatures at the sediment/basement interface, which is inferred to be a primary hydrologic contact between low-permeability sediment cover and highpermeability extrusive igneous rocks beneath. Temperatures at the contact increased systematically with distance from the region of outcropping basement, from approximately $15.5^{\circ} \mathrm{C}$ in Hole $1023 \mathrm{~A}$, to $22.4^{\circ} \mathrm{C}$ in Hole $1024 \mathrm{~B}$, and to $38.2^{\circ} \mathrm{C}$ in Hole 1025B (Table 1; Fig. 9). All temperature-depth profiles were linear, indicating conductive heat transport through the sediment column.

Holes $1024 \mathrm{C}$ and $1025 \mathrm{C}$ were designed as reentry CORK holes. These holes were cased and cemented into basement. After curing, the cement at the base of the casing was drilled out, and additional coring and drilling was continued in the basement. Permeability measurements of upper basement were attempted by setting the drill string packer in casing in Hole $1025 \mathrm{C}$, but the packer could not be set and no data were obtained. Packer measurements were successfully 
completed in basement in Hole $1024 \mathrm{C}$, however, and preliminary examination of the data suggests that basement at this site is relatively permeable. The consistency of basement lithologies and drilling difficulties between Sites 1024 and 1025 suggest that upper basement in Hole $1025 \mathrm{C}$ is also permeable.

Instrumented CORK systems (Davis et al., 1992a) were deployed in both Holes 1024C and 1025C. Each instrument package comprised a long-term data logger, two absolute pressure gauges (one for sealed hole pressures and one for seafloor pressures), a continuously operating osmotic fluid sampler (see "Methods" chapter, this volume), and 10 thermistor temperature sensors, including several thermistors positioned within basement in each hole. The first data from these instruments will be retrieved during summer 1997 using the remotely operated vehicle (ROV) Jason.

\section{Buried Basement Transect}

The sedimentary succession along the Buried Basement Transect includes three lithostratigraphic units. Subunit IA is Quaternary hemipelagic mud (clayey silt to silty clay), thin-bedded turbidites (silt to sandy silt), and thin- to thick-bedded sand turbidites. The base of Subunit IA occurs at approximately $81 \mathrm{mbsf}$ in Hole 1028A and 96 mbsf in Hole 1029A. Sand turbidites are much more common in Hole 1029A. Hole 1028A, conversely, contains more thin-bedded, fine-grained turbidites. The total number of inferred gravity-flow deposits within Subunit IA decreases from 437 at Site 1028 to 388 at Site 1029. Subunit IB is Quaternary, thinly bedded silt and sandy silt intercalated with hemipelagic mud deposits. Erratic increases in the content of calcareous nannofossils generally result in a subtle lightening of color. The top of Subunit IB was not cored at Site 1032. The base of Subunit IB occurs at depths of 107.87 mbsf (Hole 1028A), 197.39 mbsf (Hole 1029A), and 272.47 mbsf (Hole 1032A). Hemipelagic mud deposits of Unit II are Quaternary in age. The thickness of Unit II ranges from $24.6 \mathrm{~m}$ in Hole $1028 \mathrm{~A}$ to $22.7 \mathrm{~m}$ in Hole $1029 \mathrm{~A}$ to $17.8 \mathrm{~m}$ in Hole $1032 \mathrm{~A}$. The sediment/basalt contact occurs at curatorial depths of $132.48 \mathrm{mbsf}$ and $220.07 \mathrm{mbsf}$ in Holes 1028A and 1029A, respectively. The basement contact is considerably deeper $(290.29 \mathrm{mbsf})$ at Site 1032 . Sediments immediately above the basement contact display irregular color variations caused by fluctuations in primary clay-mineral content and biogenic carbonate content and/or hydrothermal formation of clay minerals and Fe-Mn oxides.

We did not subdivide sedimentary deposits from Holes 1030B and 1031A into stratigraphic units. Both holes contain 40-50 m of interbedded hemipelagic mud, carbonate-rich mud, and silt to sandy silt turbidites. The hemipelagic deposits at both sites appear to contain unusually high contents of clay-sized material. Even though both sites are perched above a prominent basement high, turbidites are significantly more abundant at Site 1030B. Basalt was recovered only from Hole 1031A. Drillers defined the basement contact at approximately 46.9 mbsf in Hole 1030B; the curatorial and drillers' basement depth in Hole 1031A is 41.30 mbsf. The lowermost deposits at Site 1030 contain abundant nannofossil-rich intervals, but there are no obvious indications of hydrothermal alteration. Basal deposits in Hole 1031A, in contrast, include variegated carbonate-rich claystone, clay-rich siliciclastic mud, and two poorly sorted silt layers with irregular top and bottom contacts and considerable internal disruption. Alteration of these sediments by fluid flow penetrating into the section above the basement contact seems likely.

Nannofossils are common to abundant in all sites along the Buried Basement Transect. They are mostly well preserved, except in Hole $1032 \mathrm{~A}$ where they exhibit moderate to strong dissolution. In Hole 1028A, the top of Gephyrocapsa lumina (130.60 mbsf) and the absence of Helicosphaera sellii in the sediment section indicate a basal sediment age younger than 1.55 Ma. In Hole 1029A, the determination of the top of Calcidiscus macintyrei in the basal sediment (220.02 mbsf) suggests an age of $1.58 \mathrm{Ma}$. The occurrence of Gephyrocapsa caribbeanica within the section of Hole 1030B indicates the basal sediment of this hole is younger than 0.76 Ma. In Hole 1031A, the top of Reticulofenestra asanoi was recognized at 37.93 mbsf; however, the base of this species (1.15 Ma) was not observed in sediments below that depth. Thus, the age of the basal sediment should be younger than $1.15 \mathrm{Ma}$. The occurrence of P. lacunosa through the section of Hole 1032A suggests that the top of the recovered section (184.52 mbsf) is older than $0.46 \mathrm{Ma}$; the absence of $\mathrm{H}$. sellii in this section implies the basal sediment is younger than $1.55 \mathrm{Ma}$. The ages of the basal sediments of these holes are several thousand years younger than basement ages (Table 1), indicating a hiatus between the formation of basalt and initial sedimentation. Sedimentation rates vary substantially between these holes and show a reduction from the eastern holes to the western holes.

Basement was recovered from Holes 1028A, 1029A, 1031A, and 1032A. All of the basement consisted predominantly of aphyric, sparsely to moderately phyric, or moderately phyric plagioclase \pm olivine \pm pyroxene and olivine \pm plagioclase basalt. All of the rocks recovered are lithologically similar pillow basalt. Subunits were identified based on the presence of chilled margins and grain-size changes within the cored sequence, allowing individual cooling units to be recognized and logged. The pillow basalts from Holes 1028A and 1029A are sparsely to moderately phyric, containing $2 \%-5 \%$ plagioclase, $1 \%-$ $2 \%$ olivine, and trace amounts of pyroxene, whereas the pillow basalts from Holes 1031A and 1032A are aphyric, containing from $\leq 1 \%$ to a trace amount of olivine, plagioclase \pm pyroxene phenocrysts. All of the basalts contain around $1 \%-3 \%$ vesicles having diameters of $\leq 1 \mathrm{~mm}$.

Secondary alteration intensity affects all rocks recovered from Sites 1028, 1029, 1031, and 1032. Secondary minerals occur as (1) vesicle or cavity linings or fillings; (2) coatings, fracture fillings, and veins; (3) replacement of phenocrysts and microphenocrysts; and (4) patches within mesostasis. The following secondary minerals were identified: clay minerals (saponite and celadonite), iddingsite, calcium carbonate, sulfides, talc, and zeolites. The alteration intensity varies, with the abundance of secondary phases ranging from $1 \%$ to $40 \%$. The intensity of glass alteration is relatively high at the Buried Basement sites, particularly at Hole 1032A. Alteration halos, 1-15 $\mathrm{mm}$ wide, are common as dark borders on rock pieces or along clay veins. Halos are distinguished by the presence of completely filled vesicles, in contrast to empty or saponite-lined and -filled vesicles in the gray, non-halo portion of the rock. The vesicle filling material is clay, commonly iddingsite and/or celadonite. Hydrothermal veins, typically $\leq 1 \mathrm{~mm}$ wide, include varieties of celadonite, saponite, aragonite, and zeolite minerals.

Alteration temperatures were low, probably less than $100^{\circ} \mathrm{C}$, and possibly no higher than the present basement temperatures of $40^{\circ}-$ $58^{\circ} \mathrm{C}$. All of the sites exhibit varying degrees of alteration, including varying degrees of oxidative alteration that required significant open seawater circulation. A subsequent stage characterized by carbonate, saponite, and sulfide alteration may represent relatively closed hydrothermal circulation.

Sediments from Holes 1028A and 1029A exhibit physical properties trends similar to those documented within sediments from the Hydrothermal Transition Transect. The mud-rich layers have lower magnetic susceptibilities, thermal conductivities, bulk densities, and $P$-wave velocities, and higher porosities, than do sand-rich layers. Porosities within muddy intervals decrease with depth, following standard compactional trends, while $P$-wave velocities increase. There is little difference between the grain density and natural gamma radiation of mud and sand layers. Cores from Holes 1030B and 1031 A contain relatively little sand, yet they do not appear to show any reduction in porosity with depth. These sediments also have lower magnetic susceptibilities and bulk densities than observed elsewhere along the transect at comparable depths. The physical properties of sediments from Hole 1032A are quite similar to those at the same depths along the Rough Basement sites.

The concentrations of organic carbon in sediments from the Buried Basement Transect are relatively low and vary broadly within the same range as at the Hydrothermal Transition and Rough Basement 
Transects. Calculated $\mathrm{C} / \mathrm{N}$ ratios indicate a predominantly marine origin for organic matter. The hydrocarbon gas content is low and dominated by methane at all sites. Concentrations of methane are significant only where dissolved sulfate is depleted and concentrations fall to background levels near the seafloor and near basement

Pore waters from sediments at Sites 1030 and 1031 provide clear evidence of upward fluid flow. For example, alkalinity normally increases significantly with depth in the absence of upward advection because of organic diagenesis; at Site 1030, it increases slightly before decreasing, and at Site 1031 alkalinity decreases monotonically with depth. Upward advection seems to be slightly faster at Site 1031 than at Site 1030, as indicated by a contrast between sulfate and ammonia concentrations. It appears that there is a balance between the input of ammonia by bacterial breakdown of organic matter and the rate at which pore-water advection removes ammonia from the sediment pores. Chloride concentrations increase with depth, approaching or slightly exceeding values believed to have been present in Pleistocene glacial seawater. Concentrations remain elevated at depth and are associated with low $\mathrm{Mg}, \mathrm{K}$, and $\mathrm{Si}$ concentrations (Table 1; Fig. 9). The elevated chloride values are significantly greater than any others seen during Leg 168. The fluid moving upward from basement over the ridge at Sites 1030 and 1031 is geochemically more mature than the fluid found at adjacent sites, showing effects of extensive hydration reactions. These observations may indicate a deeper reaction zone and/or a longer residence time in basement.

Sites 1028,1029 , and 1032 form a west to east transect to the east of the buried ridge where Sites 1030 and 1031 were drilled. The pore waters from these sites show features typical of organic diagenesis (e.g., steep decrease in sulfate and increase in alkalinity, ammonia, and phosphate with depth), inferred mineral reactivity (calcium and magnesium minima) seen elsewhere, as well as evidence for partially evolved seawater in basement (as is apparent from the increase in sulfate and calcium and decrease in alkalinity with depth).

There are additional complications to this simple picture (Fig. 9). Sulfate in near-basement pore waters is low at Site 1028 and forms a natural extension to the sequence seen at the Hydrothermal Transition sites (apart from the data from Sites 1030 and 1031). However, near-basement sulfate is higher at Site 1029 than at Site 1028, and this seems to be a break in the overall geochemical pattern. In contrast, calcium increases systematically, and values near basement at Site 1032 are considerably greater than measured at a nearby basement outcrop. This observation likely indicates that there is a reaction zone very close to the sediment/basement interface where $\mathrm{Ca}$ and $\mathrm{Na}$ are exchanged.

Sediment temperatures were measured at all sites along the Buried Basement Transect. Along the transect from west to east, Sites $1030 / 1031,1028,1029$, and 1032 have extrapolated temperatures at the sediment/basement contact of approximately $40^{\circ}, 51^{\circ}, 59^{\circ}$, and $57^{\circ} \mathrm{C}$ (Table 1; Fig. 9). The $40^{\circ} \mathrm{C}$ basement temperature at Sites 1030 and 1031 is very close to that which would be expected given the age of the lithosphere and the average sediment thickness in the area. The basement temperatures at the other sites are considerably lower than would be expected if the crust was indeed fully sealed from exchange of hydrothermal fluids with the overlying ocean. In fact, upper basement temperatures at Sites 1029 and 1032 are remarkably close to the upper basement temperature of $61^{\circ}-64^{\circ} \mathrm{C}$ at the Rough Basement Sites 1026 and 1027 , about $28 \mathrm{~km}$ to the east of Site 1032. Because of uncertainties in the actual location of the most hydrothermally active part of upper basement, these similar temperature values may indicate relative thermal homogeneity over a remarkable distance of nearly $50 \mathrm{~km}$. If fluid flow actually occurs on such a crustal scale, this will require a substantial revision to many conceptual models of heat and mass transfer in the upper oceanic crust.

Logging was completed in Hole 1032A during the last days of scientific operations of Leg 168. Although the hole had been drilled well into basement with the hope of obtaining high-quality measurements across the sediment/basement contact, hole fill and bridging problems prevented passage of the tools to this depth. Three tool strings (triple combination, Formation MicroScanner/sonic, and geochemical) were run successfully over the upper $275-280 \mathrm{~m}$ of sediment in the hole.

\section{Rough Basement Transect}

Shallow sediment cores recovered from Sites 1026 and 1027 contain interbedded sand turbidites, silt turbidites, clayey silt, and debrisflow deposits with clasts of mud in a matrix of muddy sand. This mixture of sediments was designated as lithologic Unit I at Site 1026. Interlayered sediments of the same types were designated as Unit IA at Site 1027 and extend to 184 mbsf. Unit IB at Site 1027 comprises interbeds of silt turbidites within clayey silt and silty clay, extending from 184 to 467 mbsf. The sandy intervals in Unit I were found to be thicker at Site 1027 than at Site 1026, both as represented in recovered cores and as inferred to be present over a large depth interval that yielded little or no recovery in Hole 1027B. This contrast in thickness is consistent with the local seismic structure, which shows Site 1027 to be located approximately in the center of a broad distributary channel and Site 1026 to be near the edge where the channel fill onlaps a levee of a neighboring channel system (Fig. 8). Despite the poor recovery in sandy intervals, hole conditions in Hole 1027B remained surprisingly good down to basement. Recovery improved substantially below $260 \mathrm{mbsf}$ and remained generally high until basement was reached. Lithologic Unit II was hemipelagic mudstone with variable calcium carbonate content. This unit extends from 467 to 569 mbsf in Hole 1027B. The base of Unit II coincides with the first appearance of basalt within thin interbeds of pelagic and hemipelagic mudstone. Sediment alteration was not discernible with shipboard determinations of bulk mineralogy except in the sections a few meters above basement. The most obvious signs of alteration occur in carbonate-rich sediment in immediate contact with basement. In Hole $1027 \mathrm{C}$, the basal sediments displayed vivid color variations imparted by Fe-Mn oxides.

Species diversity of nannofossils at Sites 1026 and 1027 is low, although a few key species provided some age control. E. huxleyi $(0.28 \mathrm{Ma})$ was identified throughout the $101 \mathrm{~m}$ interval drilled in Hole 1026A; the base of this zone was found at about $98 \mathrm{mbsf}$ in Hole 1027B. Other age controls in Hole 1027B include the top of $P$. lacunosa ( 0.46 Ma) at $197 \mathrm{mbsf}$, the top of C. macintyrei $(\sim 1.58 \mathrm{Ma})$ at $282 \mathrm{mbsf}$, and the base of G. lumina $(\sim 1.68 \mathrm{Ma})$ at $417 \mathrm{mbsf}$. The dominance of Reticulofenestra minuta and Reticulofenestra minutula in the assemblage below $417 \mathrm{mbsf}$, as well as the absence of $R$. pseudoumbilicus, suggests an age of late Pliocene for these deeper sediments including those interbedded with the basalt fragments at the bottom of the hole. These ages are consistent with sea-surface magnetic anomalies that constrain the age of basement at 3.51 and $3.59 \mathrm{Ma}$ at Sites 1026 and 1027, respectively. All age constraints are consistent with an increasing sedimentation rate through the history of basement burial.

Hard rock was first drilled in Hole 1026B at $247.1 \mathrm{mbsf}$. The first cored basalt recovered from Hole 1026B was from $256.0 \mathrm{mbsf}$, with basement coring continuing to a depth of $295.2 \mathrm{mbsf}$ for a total of $39.2 \mathrm{~m}$. Total recovery was $5.0 \%$. Coring of basaltic rocks in Hole $1026 \mathrm{C}$ commenced where drilling first felt basement at $228.9 \mathrm{mbsf}$. Two cores were cut to a total depth of $248.2 \mathrm{mbsf}$ for a total of 19.3 $\mathrm{m}$; total recovery was only $3.5 \%$.

Basalt was encountered in Hole 1027B during XCB coring where drilling first felt basement at a depth of 568.3 mbsf. After coring 9.6 $\mathrm{m}$ of basement in Hole 1027B, Hole 1027C was begun with the objective of casing into basement and then coring further below the cemented casing shoe for a CORK installation. In Hole 1027C, diabase was first recovered from $584.8 \mathrm{mbsf}$, or $9.3 \mathrm{~m}$ below the first hard rock felt by the drillers at $575.5 \mathrm{mbsf}$, and coring continued for an- 
other $47.6 \mathrm{~m}$. Core 168-1027C-1R consisted of diabase, whereas all of Core $2 \mathrm{R}$ and most of Core $3 \mathrm{R}$ contained terrigenous clay and pelagic sediments. The last $28 \mathrm{~cm}$ of Core 168-1027C-3R and all of Cores $4 \mathrm{R}$ and $5 \mathrm{R}$ contained fractured pillow basalts. Total recovery was $10 \%$ in the XCB core from Hole $1027 \mathrm{~B}, 73 \%$ in a massive diabase unit from Core 168-1027C-1R, and $36 \%$ and $73 \%$ in fractured pillow basalts from Cores 168-1027C-4R and 5R, respectively.

The basaltic rock types recovered at the two Rough Basement sites vary significantly. The rocks from Hole 1026B are divided into three units. Unit 1 is slightly to moderately altered aphyric plagioclase-pyroxene basalt, Unit 2 is a highly altered basalt-hyaloclastite breccia, and Unit 3 consists of a slightly to moderately altered aphyric basalt and moderately phyric pyroxene-plagioclase-olivine basalt. All three units exhibit sparse, thin glass margins, with all basalts containing sparse $(<1 \%)$, small $(<1 \mathrm{~mm}$ diameter) vesicles. The rocks may represent a complex of pillow basalts and interpillow basalthyaloclastite breccia. Hole $1026 \mathrm{C}$ consists of pillow basalts, designated Unit 1; these are also sparsely phyric, slightly to moderately altered basalts with several occurrences of glassy margins.

At the deeper basement site (Site 1027), four distinct units were identified. In Hole 1027B, Unit 1 is a massive aphyric olivineplagioclase-pyroxene basalt with slight to moderate alteration. Unit 2 , separated from Unit 1 by at least $15 \mathrm{~cm}$ of hemipelagic or pelagic carbonate-bearing mud, is a basaltic breccia containing fragments of basalt similar to that of Unit 1 . The first rock cored in Hole $1027 \mathrm{C}$ is Unit 3, which is a fine-grained plagioclase-olivine-pyroxene diabase with an aphanitic lower chilled margin; the upper margin was not sampled. Alteration varies from slight to moderate between the diabasic core and the aphanitic margin. Below Unit 3 is at least $10.6 \mathrm{~m}$ ( $23.0 \mathrm{~m}$ according to the driller's record) of terrigenous clay and bedded, altered, and deformed carbonate-rich pelagic sediments. Consequently, Unit 3 is interpreted as a sill that was emplaced off-axis. The final $19 \mathrm{~m}$ of coring in Hole $1027 \mathrm{C}$ recovered portions of a pillow basalt sequence, recognized by abundant glassy chilled margins (every 0.6-1.2 m, on average). These pillow basalts are slightly to moderately altered, aphyric to moderately phyric plagioclase-olivine and plagioclase-olivine-pyroxene basalts. All four igneous units from Site 1027 contain sparse $(<1 \%)$, small $(<1 \mathrm{~mm}$ diameter $)$ vesicles.

Major-element X-ray fluorescence analyses show all the rocks to be low-potassium tholeiitic basalts with variable magnesium numbers. The diabase of Hole $1027 \mathrm{C}$ and the massive basalts of Hole 1027B, however, differ significantly from the pillow basalts from Holes $1027 \mathrm{C}, 1026 \mathrm{~B}$, and 1026C. The pillow basalt geochemistry defines well-constrained linear variation diagrams, suggesting that they may all be related through simple low-pressure fractionation of olivine, plagioclase, and/or clinopyroxene. In contrast, the diabase and Hole 1027B massive basalts have very similar chemical compositions, which lie off the fractionation trends defined by the pillow basalts. This suggests that the two distinct chemical groups represent different magmatic events. The pillow basalts were probably erupted in an axial or near-axial environment, whereas the diabase and massive basalts must have erupted onto or intruded into the sediment section off-axis at a later stage.

Alteration effects in basalt from Sites 1026 and 1027 vary significantly between lithologic units, although certain features are ubiquitous. Nearly all samples contain mineral linings or complete mineral fillings of vesicles. Frequently, the vesicle filling involves two to four sequential layers. The observed distribution of the various vesicle fills is systematic and is linked to the proximity of the vesicles to veins and alteration halos. In addition, veins and mineral coatings occur on fractured rock surfaces. A third mode of alteration is the replacement by clays of magmatic phases including phenocrysts, groundmass crystals, cryptocrystalline mesostasis, and glass.

In summary, petrological studies at Sites 1026 and 1027 suggest the presence of two distinct magmatic series with distinct alteration histories. Pillow basalts from Site 1026 and from the deepest cores at
Site 1027 represent petrogenetically related mid-ocean ridge basalts with abundant early oxidative alteration, which is probably the result of extended exposure of the rocks at the seafloor. In contrast, the diabase and the massive basalts from Hole 1027B and the first core of Hole $1027 \mathrm{C}$ are petrogenetically distinct from the pillow basalts and represent the products of off-axis magmatism; these rocks did not experience significant oxidative alteration by seawater. Finally, an overprint of calcium carbonate alteration affects all of the rocks at Site 1027, whereas calcium carbonate is only a minor alteration product at Site 1026. The reason for this difference may relate to the locations of Site 1026 (drilled into a buried ridge) and Site 1027 (in a buried valley) and consequent differences in the hydrothermal regime.

Profiles of inorganic pore-water composition at the two sites follow similar trends and reflect reaction with sediments, flow of incompletely altered waters in basaltic basement, water/rock reactions in basement, and temporal variations in the composition of bottom water from glacial and interglacial periods. Although the chemical data do not indicate significant flow of pore fluids vertically through the sediments, when Hole 1026B was reentered immediately before deploying the CORK in that hole, temperatures within the borehole indicated that basement water was flowing from the formation into the hole, up through casing, and into the overlying ocean. Basementfluid pressure at this location must therefore be locally super-hydrostatic, but the low permeability of the sediment section must limit natural fluid seepage to a rate below that which is geochemically detectable. A water-sampling temperature probe coupled with a coring temperature tool was run into the hole to collect a sample of the discharging basement fluid and to complete the log of temperatures in the borehole so that the fluid velocity could be estimated. This was the first successful sampling of true basement fluid in the history of the Deep Sea Drilling Project and ODP. The sample was sufficiently large to allow post-cruise carbon-14 analyses to determine the age or a limiting age of the hydrothermal fluid. To a first order, this basement fluid has the same composition as the fluid exiting from the nearest basement outcrop that has been sampled by submersible. It differs in several notable respects from the composition suggested by interstitial water samples collected from sediments just above basement.

Methane concentrations increased from near zero near the seafloor and basement to values on the order of $10^{4}$ parts per million (ppm) by volume in midsections of sediment cored at Sites 1026 and 1027. Ethane also was present at low concentrations in headspace samples. Pentane and minor light alkene hydrocarbon gases $(<1 \mathrm{ppm})$ were present at $360 \mathrm{mbsf}$ at Site 1027 . The methane/ethane ratio decreased from 26,000 at $200 \mathrm{mbsf}$ to 900 at the base of the sediment section.

Physical properties measurements within the sediment section revealed the expected effects of consolidation and lithification with depth, with local variations associated with changes in sand, silt, and clay contents. $P$-wave velocities measured in the laboratory at atmospheric pressure are near $1.5 \mathrm{~km} / \mathrm{s}$ at the seafloor and increase to 1.7 to $1.9 \mathrm{~km} / \mathrm{s}$ near basement. Velocities of the mudstone in Unit II were found to be anisotropic, with horizontal velocities greater than vertical. MST magnetic susceptibility and gamma-ray attenuation porosity evaluator data allowed rapid delineation of fining-upward turbidite sequences as well as relatively homogeneous sandy intervals (where these were recovered) before the core was split, facilitating the selection of whole-round physical properties samples collected for shore-based studies.

As at the previous sites, temperatures were measured in the sediment section with the goal of obtaining accurate determinations of the temperature of the sediment/basement interface, which is inferred to be a primary hydrologic contact between low-permeability sediment cover and high-permeability extrusive igneous rocks beneath. At Site 1026, the temperature at the contact estimated by extrapolation of advanced hydraulic piston corer and Davis/Villinger Temper- 
ature Probe measurements is approximately $61^{\circ}-62^{\circ} \mathrm{C}$, only slightly lower than that at the extrusive contact at Site 1027 , about $63^{\circ} \mathrm{C}(\mathrm{Ta}-$ ble 1). These temperatures represent only lower limits for those of "hydrologic basement" because the first zone of high permeability at any given location will probably lie deeper than the sediment/basement contact. This is illustrated well by the lack of agreement between the sediment/basement contact temperature estimated at Site $1026\left(\sim 61^{\circ}-62^{\circ} \mathrm{C}\right)$ and the measured temperature of discharging basement water $\left(\sim 64^{\circ} \mathrm{C}\right)$. Uncertainties of this magnitude preclude resolving whether hydrothermal temperatures are systematically warmer at the ridge or the valley. Resolution of this question should be possible following examination of data from the long-term CORK installations at these sites. At this time it can only be concluded that upper basement temperatures are uniform to within a few degrees.

Successful packer experiments were conducted in both Holes $1026 \mathrm{~B}$ and $1027 \mathrm{C}$. The packer was set first in casing at the base of Hole 1026B. Basement pressures recorded while the packer element was inflated (isolating the open hole) indicate a slight underpressure after correction for the cold hydrostatic water column in the borehole, although later flow from the formation into the borehole indicates that the formation is naturally overpressured. The retention of a basement underpressure at the end of the Hole 1026B packer tests suggests that there is a good seal between the casing and formation and, thus, that the CORK experiment should allow ambient basementfluid pressures to be determined accurately. Results of two slug tests are consistent with relatively high basement permeability, although interpretation of packer tests in Hole 1026B will be complicated by the non-ideal hole geometry because much of the hole below the casing shoe was filled with basalt rubble.

In Hole $1027 \mathrm{C}$, the packer was set first in the casing above the open hole. Three slug tests and two injection tests indicate relatively high permeability. The packer was also set below the casing in Hole $1027 \mathrm{C}$, within the massive basalt flow unit recovered in Core 1681027C-1R. Two additional slug tests and two injection tests also indicate high permeability. There also appeared to be an underpressure in Hole $1027 \mathrm{C}$, although the magnitude of this underpressure was somewhat lower than that in Hole 1026B. An accurate determination of the natural formation pressure will be made during the long-term CORK experiment.

CORK observatories were set in Holes 1026B and 1027C. Each observatory included a data logger, pressure gauges above and below the borehole seal, a thermistor string with 10 sensors, and an osmotic sampler above a sinker bar at the bottom of the thermistor cable. Poor drilling conditions in Hole 1026B led to the emplacement of a "liner," a piece of old drill pipe attached to a modified mechanical bit release, that was drilled into the formation and left to hold open the hole. Drilling conditions were considerably better in Hole 1027C, and no liner was required to maintain the hole. Once open holes were established, both CORK systems were emplaced with little difficulty. The first data will be downloaded in the summer of 1997 during an expedition with the ROV Jason.

\section{REFERENCES}

Alt, J.C., Honnorez, J., Laverne, C., and Emmermann, R., 1986. Hydrothermal alteration of a $1 \mathrm{~km}$ section through the upper oceanic crust, Deep Sea Drilling Project Hole 504B: mineralogy, chemistry, and evolution of seawater-basalt interactions. J. Geophys. Res., 91:10309-10335.

Anderson, R.N., Langseth, M.G., and Sclater, J.G., 1977. The mechanisms of heat transfer through the floor of the Indian Ocean. J. Geophys. Res., 82:3391-3409.

Becker, K., and Von Herzen, R.P., 1983. Heat transfer through the sediments of the Mounds Hydrothermal area, Galapagos Spreading Center at $86^{\circ} \mathrm{W}$. J. Geophys. Res., 88:995-1008.

Cande, S.C., and Kent, D.V., 1995. Revised calibration of the geomagnetic polarity timescale for the Late Cretaceous and Cenozoic. J. Geophys. Res., 100:6093-6095.
Currie, R.G., Seemann, D.S., and Riddihough, R.P., 1982. Total magnetic field anomaly, offshore British Columbia. Open File Rep.-Geol. Surv. Can., 828.

Davis, E.E., and Becker, K., 1994. Formation temperatures and pressures in a sedimented rift hydrothermal system: ten months of CORK observations, Holes 857D and 858G. In Mottl, M.J., Davis, E.E., Fisher, A.T., and Slack, J.F. (Eds.), Proc. ODP, Sci. Results, 139: College Station, TX (Ocean Drilling Program), 649-666.

Davis, E.E., Becker, K., Pettigrew, T., Carson, B., and MacDonald, R., 1992a. CORK: a hydrologic seal and downhole observatory for deepocean boreholes. In Davis, E.E., Mottl, M.J., Fisher, A.T., et al., Proc. ODP, Init. Repts., 139: College Station, TX (Ocean Drilling Program), 43-53.

Davis, E.E., Chapman, D.S., Forster, C.B., and Villinger, H., 1989. Heat-flow variations correlated with buried basement topography on the Juan de Fuca ridge flank. Nature, 342:533-537.

Davis, E.E., Chapman, D.S., Mottl, M.J., Bentkowski, W.J., Dadey, K., Forster, C., Harris, R., Nagihara, K., Rohr, K., Wheat, G., and Whiticar, M.J., 1992b. Flankflux: an experiment to study the nature of hydrothermal circulation in young oceanic crust. Can. J. Earth Sci., 29:925-952.

Davis, E.E., and Currie, R.G., 1993. Geophysical observations of the northern Juan de Fuca Ridge system: lessons in sea-floor spreading. Can. J. Earth Sci., 30:278-300.

Davis, E.E., Currie, R.G., and Sawyer, B.S., 1987. Marine geophysical maps of western Canada. Geol. Surv. Can., Maps 2-1987 through 17-1987 (scale 1:250,000).

Davis, E.E., Wang, K., He, J., Chapman, D.S., Villinger, H., and Rosenberger, A., 1997. An unequivocal case for high Nusselt-number hydrothermal convection in sediment-buried igneous oceanic crust. Earth Planet. Sci. Lett., 146:137-150.

Donnelly, T.W., Thompson, G., and Salisbury, M.H., 1980. The chemistry of altered basalts at Site 417, DSDP Leg 51. In Donnelly, T., Francheteau, J., Bryan, W., Robinson, P., Flower, M., Salisbury, M., et al., Init. Repts. DSDP, 51, 52, 53 (Pt. 2): Washington (U.S. Govt. Printing Office), 13191330 .

Fisher, A.T., and Becker, K., 1995. Correlation between seafloor heat flow and basement relief: observational and numerical examples and implications for upper crustal permeability. J. Geophys. Res., 100:12641-12657.

Fisher, A.T., Becker, K., Narasimhan, T.N., Langseth, M.G., and Mottl, M.J., 1990. Passive, off-axis convection through the southern flank of the Costa Rica rift. J. Geophys. Res., 95:9343-9370.

Green, K.C., Von Herzen, R.P., and Williams, D.L., 1981. The Galapagos spreading center at $86^{\circ} \mathrm{W}$ : a detailed geothermal field study. J. Geophys. Res., 86:979-986.

Hartline, B.K., and Lister, C.R.B., 1981. Topographic forcing of supercritical convection in a porous medium such as the oceanic crust. Earth Planet. Sci. Lett., 55:75-86.

Houtz, R., and Ewing, J., 1976. Upper crustal structure as a function of plate age. J. Geophys. Res., 81:2490-2498.

Johnson, H.P., and Holmes, M.L., 1989. Evolution in plate tectonics: a study of the Juan de Fuca Ridge. In Winterer, E.L., Hussong, D.M., and Decker, R.E. (Eds.), The Eastern Pacific Ocean and Hawaii. Geol. Soc. Am., Geol. of North Am. Ser., N:73-91.

Kappel, E.S., and Ryan, W.B.F., 1986. Volcanic episodicity and a non-steady state rift valley along Northeast Pacific spreading centers: evidence from Sea MARC I. J. Geophys. Res., 91:13925-13940.

Langseth, M.G., Becker, K., Von Herzen, R.P., and Schultheiss, P., 1992. Heat and fluid flux through the sediment on the western flank of the MidAtlantic Ridge: a hydrological study of North Pond. Geophys. Res. Lett., 19:517-520.

Langseth, M.G., Hyndman, R., Becker, K., Hickman, S.H., and Salisbury, M., 1984. The hydrogeologogical regime of isolated sediment ponds in mid-oceanic ridges. In Hyndman, R.D., Salisbury, M.H., et al., Init. Repts. DSDP, 78 (Pt. 2): Washington (U.S. Govt. Printing Office), 825837.

Langseth, M.G., Mottl, M.J., Hobart, M.A., and Fisher, A., 1988. The distribution of geothermal and geochemical gradients near Site 501/504: implications for hydrothermal circulation in the oceanic crust. In Becker, K., Sakai, H., et al., Proc. ODP, Init. Repts., 111: College Station, TX (Ocean Drilling Program), 23-32.

Lister, C.R.B., 1972. On the thermal balance of a mid-ocean ridge. Geophys. J. R. Astron. Soc., 26:515-535.

1977. Estimates for heat flow and deep rock properties based on boundary layer theory. Tectonophysics, 41:157-171. 
Lowell, R.P., 1980. Topographically driven subcritical hydrothermal convection in the oceanic crust. Earth Planet. Sci. Lett., 49:21-28.

Mottl, M.J., 1989. Hydrothermal convection, reaction, and diffusion in sediments on the Costa Rica Rift flank: pore-water evidence from ODP Sites 677 and 678. In Becker, K., Sakai, H., et al., Proc. ODP, Sci. Results, 111: College Station, TX (Ocean Drilling Program), 195-213.

Parsons, B., and Sclater, J., 1977. An analysis of the variation of ocean floor bathymetry and heat flow with age. J. Geophys. Res., 82:803-827.

Purdy, G.M., 1987. New observations of the shallow seismic structure of young oceanic crust. J. Geophys. Res., 92:9351-9362.

Rohr, K., 1994. Increase of seismic velocities in upper oceanic crust and hydrothermal circulation in the Juan de Fuca plate. Geophys. Res. Lett., 21:2163-2166.

Sclater, J.G., Crowe, J., and Anderson, R.N., 1976. On the reliability of ocean heat flow averages. J. Geophys. Res., 81:2997-3006.

Sclater, J.G., Jaupart, C., and Galson, D., 1980. The heat flow through oceanic and continental crust and the heat loss of the Earth. Rev. Geophys. Space Phys., 18:269-311.

Shipboard Scientific Party, 1992. Site 858. In Davis, E.E., Mottl, M.J., Fisher, A.T., et al., Proc. ODP, Init. Repts., 139: College Station, TX (Ocean Drilling Program), 431-569.

Thomson, R.E., Davis, E.E., and Burd, B.J., 1995. Hydrothermal venting and geothermal heating in Cascadia Basin. J. Geophys. Res., 100:6121-6141.
Von Herzen, R.P., Cordery, M.J., Detrick, R.S., and Fang, C., 1989. Heat flow and the thermal origin of hot spot swells: the Hawaiian swell revisited. J. Geophys. Res., 94:13783-13799.

Von Herzen, R.P., Detrick, R.S., Crough, S.T., Epp, D., and Fehn, U., 1982 Thermal origin of the Hawaiian swell: heat flow evidence and thermal models. J. Geophys. Res., 87:6711-6723.

Wang, K., He, J., and Davis, E.E., 1997. Influence of basement topography on hydrothermal circulation in sediment-buried igneous oceanic crust. Earth Planet. Sci. Lett., 146:151-164.

Wheat, C.G., and Mottl, M.G., 1994. Hydrothermal circulation, Juan de Fuca Ridge eastern flank: factors controlling basement water composition. $J$. Geophys. Res., 99:3067-3080.

Wilkens, R.H., Fryer, G.J., and Karsten, J., 1991. Evolution of porosity and seismic structure of upper oceanic crust: importance of aspect ratios. $J$. Geophys. Res., 96:17891-17995.

Williams, D.L., and Von Herzen, R.P., 1974. Heat loss from the Earth: new estimate. Geology, 2:327-330.

Williams, D.L., Von Herzen, R.P., Sclater, J.G., and Anderson, R.N., 1974. The Galapagos spreading centre: lithospheric cooling and hydrothermal circulation. Geophys. J. R. Astron. Soc., 38:587-608.

Ms 168IR-101 